\title{
Changing Landscape of the Coal Mining Industry in the United States
}

\author{
Maria Mastalerz and Agnieszka Drobniak \\ Indiana Geological and Water Survey, Indiana University, Bloomington, Indiana \\ E-mail: agdrobni@indiana.edu \\ Received 01/01/2020 \\ Accepted for publication 01/01/2020 \\ Published 04/27/2020 \\ Suggested citation: Mastalerz, M., and Drobniak, A., 2020, Changing landscape of the coal mining industry in the United States: \\ Indiana Geological and Water Survey, Indiana Journal of Earth Sciences, v. 2. DOI 10.14434/ijes.v2i1.28585
}

\begin{abstract}
Coal has been a valuable natural resource in the United States throughout the country's history. European settlers began to use coal for heating in the late 1740s and, as energy demands increased, coal production climbed from 9.3 million tons in 1850 to 750 million in 1918. Eventually coal replaced wood as the primary energy source, and by the 1940s, coal was providing up to 75 percent of U.S. energy needs.

In the United States, bituminous coal was the first target of the coal mining industry. This changed between 1843 and 1868 when more anthracite began to be mined. Used in iron smelting, this cleaner and smokeless alternative became the preferred fuel in cities. However, limited anthracite resources could not fulfill increasing demand. The production of sub-bituminous coal began to slowly rise, and in 2010 it was greater than bituminous coal production. Until the 1950s, coal was mined primarily using underground methods. By the 1970s, however, the development of cheaper surface mining proved a viable alternative for the U.S. coal industry.

Over the last 10 years, coal production in the United States dropped 37 percent, from about 1.1 billion to about 702 million tons in 2017, and the number of active coal mines also declined. Coal consumption declined as a result of an increased supply of cheaper and cleaner natural gas, the growth of renewable energy sources, and enforced environmental regulations. Coal provided close to 60 percent of U.S. electricity in the mid-1980s, but only about 30 percent in 2017. While there were 606 coal-burning power plants in 2007, only 359 were operating in 2017, with the remainder closed because of aging infrastructure and stiffer environmental guidelines.

Coal mining is an industry in transition-new technologies and policies continually to reshape the energy landscape. With increased competition from other sources of energy, a steady decline in the number of coal-fired power plants, and increasing public perception of coal as a dirty fuel, the coal industry faces even more changes.
\end{abstract}




\section{U.S. COAL IN THE WORLD CONTEXT}

At the end of 2017, more than 1.03 trillion tons of coal reserves were estimated to remain in the world's coal basins (BP, 2018) (Table 1, fig. 1). Coal reserves in North America account for 25 percent of the world resource (fig. 2), and the United States, having the world's largest proven reserves (250.9 billion tons), accounts for 24.2 percent (Table 1, fig. 3).

According to data from BP, 5,276.04 million tons of coal were produced worldwide in 2017, a 2.7 percent increase after production fell for the previous three years (BP, 2018) (Table 2). This increase was, to a large extent, caused by a 3.6 percent increase in coal production in China, which in 2017 produced 2,446.08 million tons (BP, 2018). China is the largest coal producer in the world, followed by the United States and India (fig. 4). The Asia-Pacific region, with China, India, and Australia as leading coal producers, accounts for 71.7 percent of the world's output, compared to 10.8 percent from North America (fig. 5).

World coal consumption was 5,224.10 million tons in 2017, a level roughly maintained since 2011 (Table $3 \mathrm{~A}, \mathrm{~B})$. China is not only the largest producer of coal, it also uses the greatest amount of coal (fig. 6). Coal consumption in the United States has decreased over the last decade. Coal consumption trends follow those of coal production, with the Asia-Pacific region as the number one consumer (74.5 percent) (fig. 7). Although world coal production has maintained a steady level over the last several years, coal's position as a world energy source fell to 27.6 percent in 2017, the lowest since 2004 (BP, 2018).

\section{COAL IN THE UNITED STATES}

In the United States, coal is found in a number of basins and varies in rank from lignite to anthracite (fig. 8). An estimate from the U.S. Energy Information Administration (EIA) shows that the demonstrated coal reserve base (DRB) in the United States was 430,900 million tons as of 2018 (EIA, 2018a). In comparison, 2018 BP data calculates 250,916 million tons of proven reserves (Table 1). The BP calculation takes into account property rights, land use conditions, and physical and environmental restrictions, and estimates that about 53 percent of the DRB would be available for mining (EIA, 2018a). Considering current (2019) U.S. coal production, reserves will last for more than 200 years (BP, 2018).

The history of coal mining in the United States dates back to the fourteenth century and the use of coal by the Hopi Indians for firing pottery and heating their homes (French and Hanes, 2006). The 1740s mark the first use of coal in Virginia by European colonists (EIA, 1992). At the beginning of the nineteenth century, almost all of the coal produced was bituminous, and only a small amount of anthracite was mined. However, anthracite

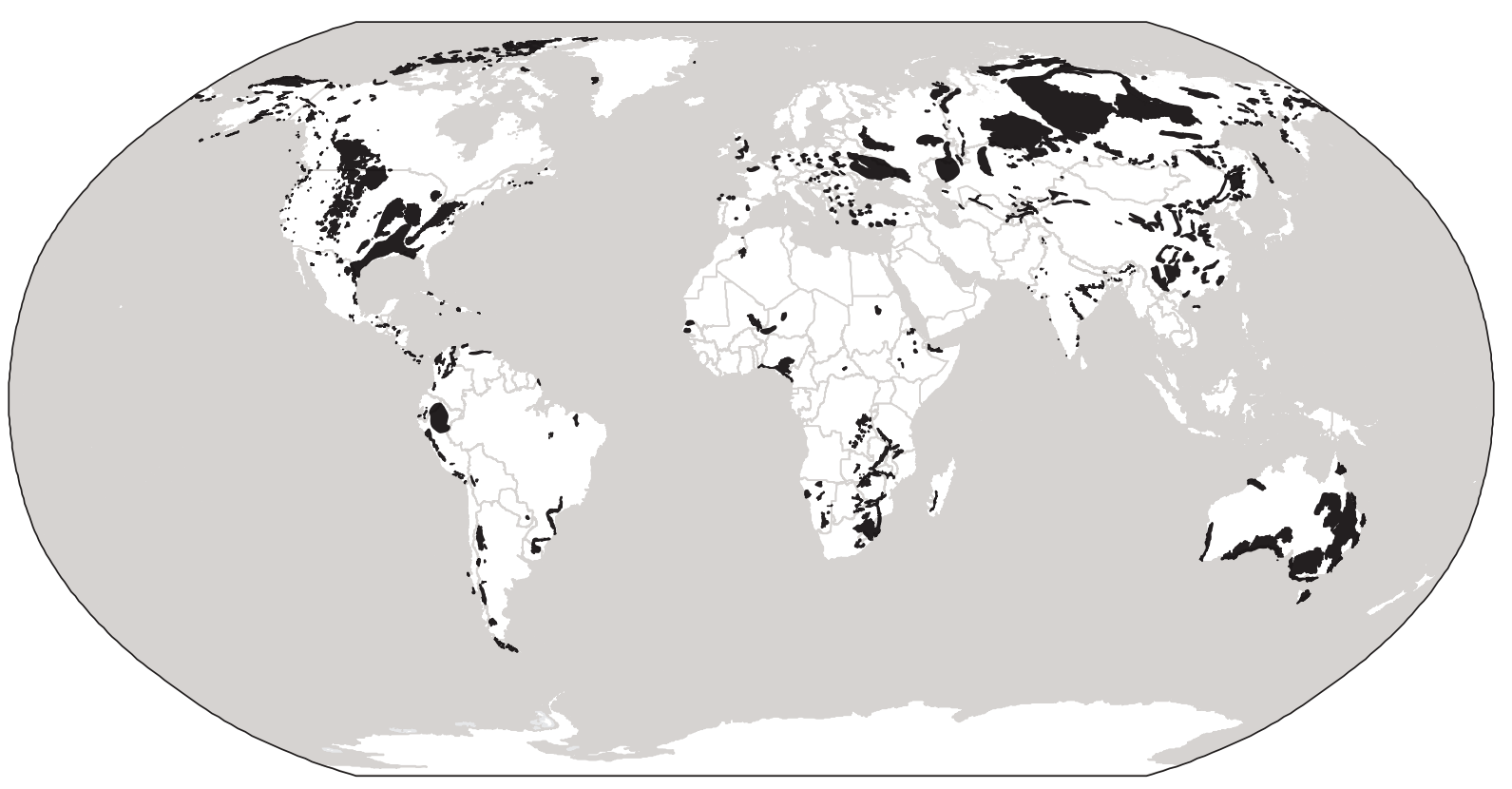

Figure 1. Map showing the major coal basins of the world. Compiled from Brownfield and others (2001); Karlsen and others (2001); Merrill and Tewalt (2008); Tewalt and others (2008); Trippi and Tewalt (2011); Jaireth and Huleatt (2012); Euracoal (2012). 
Table 1. Total proven reserves at the end of 2017 (in million metric tons) (BP, 2018). CIS = Commonwealth of Independent States (Russian Commonwealth)

\begin{tabular}{|c|c|c|c|c|}
\hline $\begin{array}{l}\text { COAL RESERVES } \\
\text { Million metric tons }\end{array}$ & $\begin{array}{l}\text { Anthracite and } \\
\text { bituminous }\end{array}$ & $\begin{array}{l}\text { Sub-bituminous } \\
\text { and lignite }\end{array}$ & Total & Share of total \\
\hline US & 220,800 & 30,116 & 250,916 & $24.20 \%$ \\
\hline Canada & 4,346 & 2,236 & 6,582 & $0.60 \%$ \\
\hline Mexico & 1,160 & 51 & 1,211 & $0.10 \%$ \\
\hline Total North America & 226,306 & 32,403 & 258,709 & $25.00 \%$ \\
\hline Brazil & 1,547 & 5,049 & 6,596 & $0.60 \%$ \\
\hline Colombia & 4,881 & - & 4,881 & $0.50 \%$ \\
\hline Venezuela & 731 & - & 731 & $0.10 \%$ \\
\hline Other S. \& Cent. America & 1,784 & 24 & 1,808 & $0.20 \%$ \\
\hline Total S. \& Cent. America & 8,943 & 5,073 & 14,016 & $1.40 \%$ \\
\hline Bulgaria & 192 & 2,174 & 2,366 & $0.20 \%$ \\
\hline Czech Republic & 1,099 & 2,541 & 3,640 & $0.40 \%$ \\
\hline Germany & 8 & 36,100 & 36,108 & $3.50 \%$ \\
\hline Greece & - & 2,876 & 2,876 & $0.30 \%$ \\
\hline Hungary & 276 & 2,633 & 2,909 & $0.30 \%$ \\
\hline Poland & 19,808 & 6,003 & 25,811 & $2.50 \%$ \\
\hline Romania & 11 & 280 & 291 & $\bullet$ \\
\hline Serbia & 402 & 7,112 & 7,514 & $0.70 \%$ \\
\hline Spain & 868 & 319 & 1,187 & $0.10 \%$ \\
\hline Turkey & 378 & 10,975 & 11,353 & $1.10 \%$ \\
\hline United Kingdom & 70 & - & 70 & $\cdot$ \\
\hline Other Europe & 1,108 & 5,172 & 6,280 & $0.60 \%$ \\
\hline Total Europe & 24,220 & 76,185 & 100,405 & $9.70 \%$ \\
\hline Kazakhstan & 25,605 & - & 25,605 & $2.50 \%$ \\
\hline Russian Federation & 69,634 & 90,730 & 160,364 & $15.50 \%$ \\
\hline Ukraine & 32,039 & 2,336 & 34,375 & $3.30 \%$ \\
\hline Uzbekistan & 1,375 & - & 1,375 & $0.10 \%$ \\
\hline Other CIS & 1,509 & - & 1,509 & $0.10 \%$ \\
\hline Total CIS & 130,162 & 93,066 & 223,228 & $21.60 \%$ \\
\hline South Africa & 9,893 & - & 9,893 & $1.00 \%$ \\
\hline Zimbabwe & 502 & - & 502 & - \\
\hline Other Africa & 2,756 & 66 & 2,822 & $0.30 \%$ \\
\hline Middle East & 1,203 & - & 1,203 & $0.10 \%$ \\
\hline Total Middle East \& Africa & 14,354 & 66 & 14,420 & $1.40 \%$ \\
\hline
\end{tabular}

\section{- Less than $0.05 \%$}


Table 1. (continued) Total proven reserves at the end of 2017 (in million metric tons) (BP, 2018). CIS = Commonwealth of Independent States (Russian Commonwealth)

\begin{tabular}{|c|c|c|c|c|}
\hline $\begin{array}{c}\text { COAL RESERVES } \\
\text { Million metric tons }\end{array}$ & $\begin{array}{c}\text { Anthracite and } \\
\text { bituminous }\end{array}$ & $\begin{array}{c}\text { Sub-bituminous } \\
\text { and lignite }\end{array}$ & Total & Share of total \\
\hline Australia & 68,310 & 76,508 & 144,818 & $14.00 \%$ \\
\hline China & 130,851 & 7,968 & 138,819 & $13.40 \%$ \\
\hline India & 92,786 & 4,942 & 97,728 & $9.40 \%$ \\
\hline Indonesia & 15,068 & 7,530 & 22,598 & $2.20 \%$ \\
\hline Japan & 340 & 10 & 350 & - \\
\hline Mongolia & 1,170 & 1,350 & 2,520 & $0.20 \%$ \\
\hline New Zealand & 825 & 6,750 & 7,575 & $0.70 \%$ \\
\hline Pakistan & 207 & 2,857 & 3,064 & $0.10 \%$ \\
\hline South Korea & 326 & - & 326 & $0.30 \%$ \\
\hline Thailand & - & 1,063 & 1,063 & $0.20 \%$ \\
\hline Vietnam & 3,116 & 244 & 3,360 & $\mathbf{4 1 . 0 0 \%}$ \\
\hline Other Asia Pacific & 1,326 & 687 & 2,013 & $\mathbf{1 0 0 . 0 0 \%}$ \\
\hline Total Asia Pacific & $\mathbf{3 1 4 , 3 2 5}$ & $\mathbf{1 0 9 , 9 0 9}$ & $\mathbf{4 2 4 , 2 3 4}$ & \\
\hline \multicolumn{5}{|l|}{} \\
\hline \multicolumn{7}{|c|}{ TOTAL WORLD } & $\mathbf{7 1 8 , 3 1 0}$ & $\mathbf{3 1 6 , 7 0 2}$ & $\mathbf{1 , 0 3 5 , 0 1 2}$ & \\
\hline
\end{tabular}

- Less than $0.05 \%$

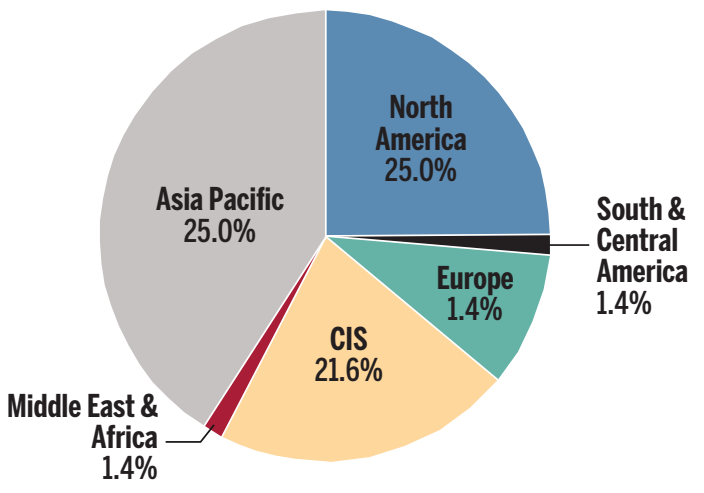

Figure 2. Distribution of proven coal reserves at the end of 2017 (BP, 2018).

$\mathrm{CIS}=$ Commonwealth of Independent States (Russian Commonwealth).

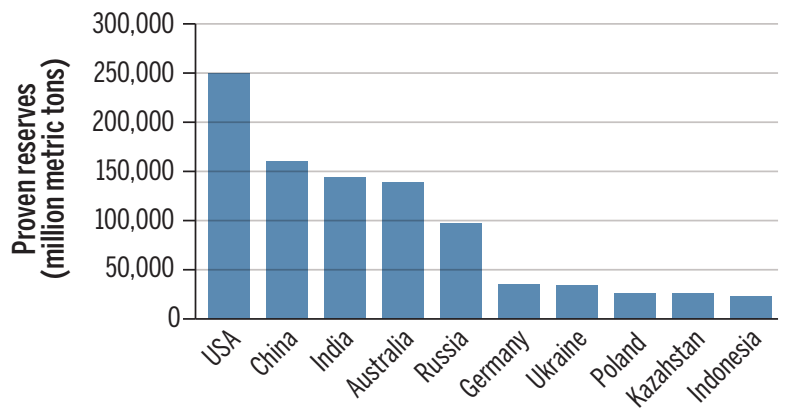

Figure 3. Proven coal reserves in the top ten coal-producing countries at the end of 2017 (in million metric tons) (BP, 2018). 


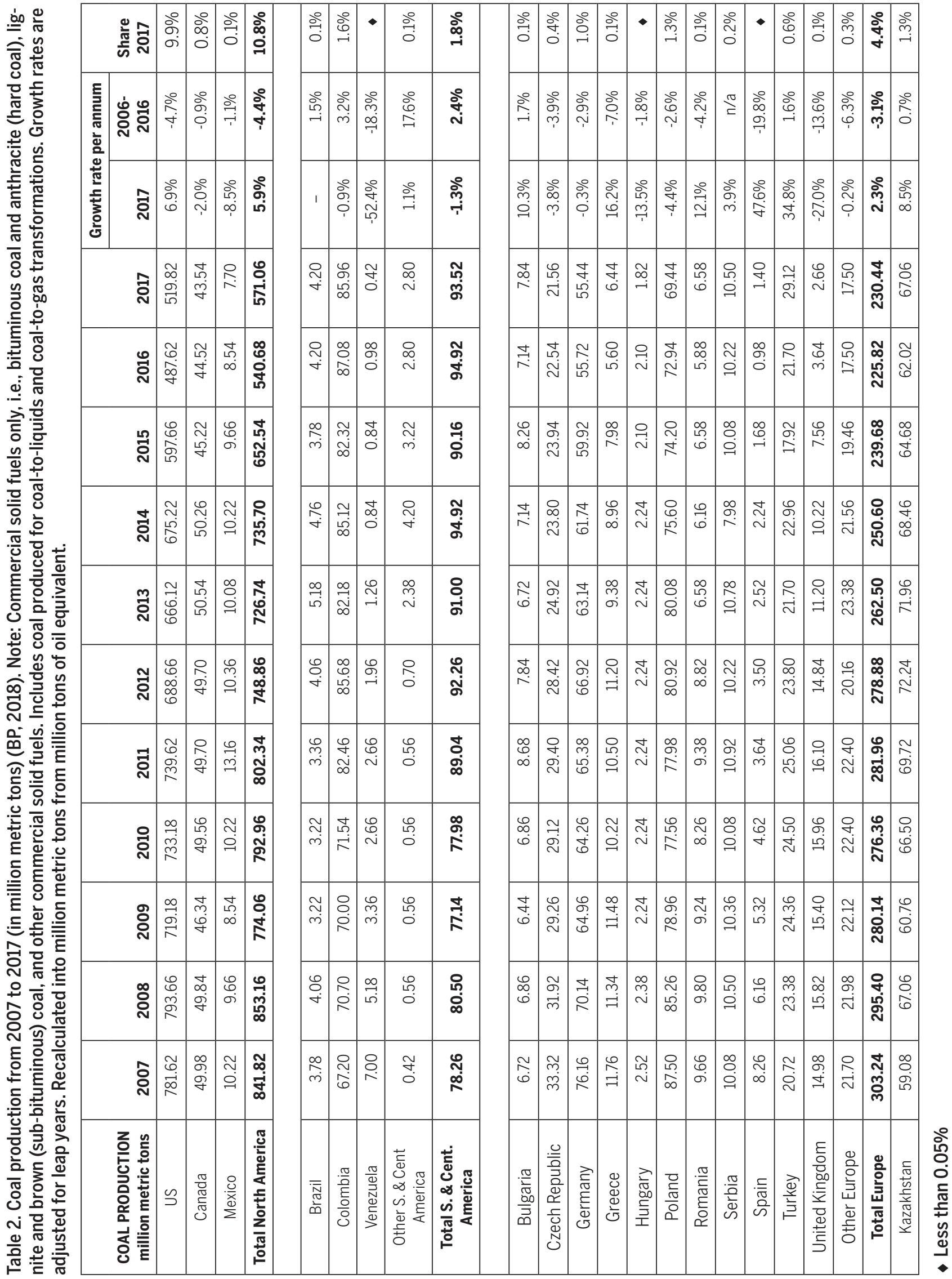




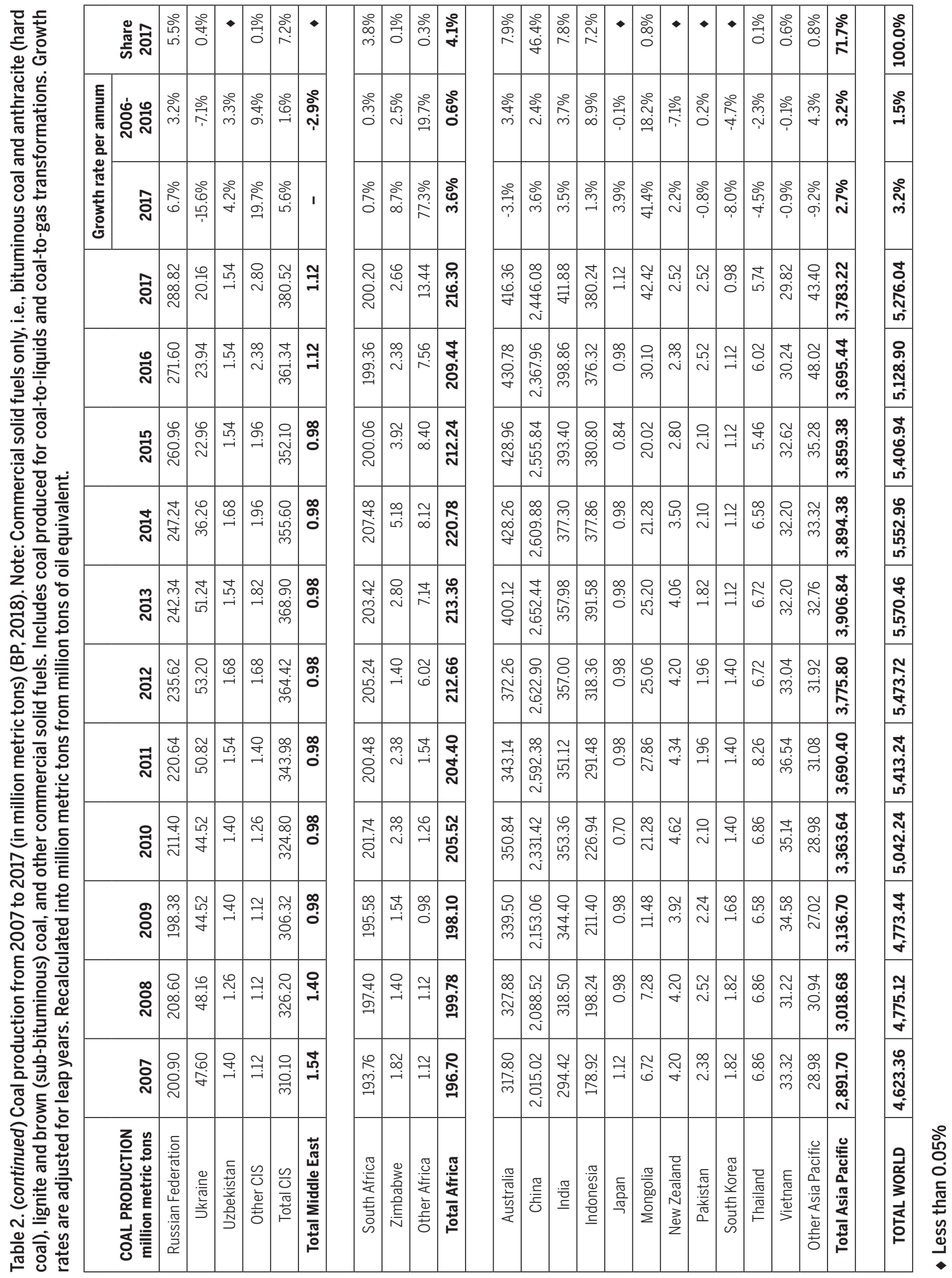




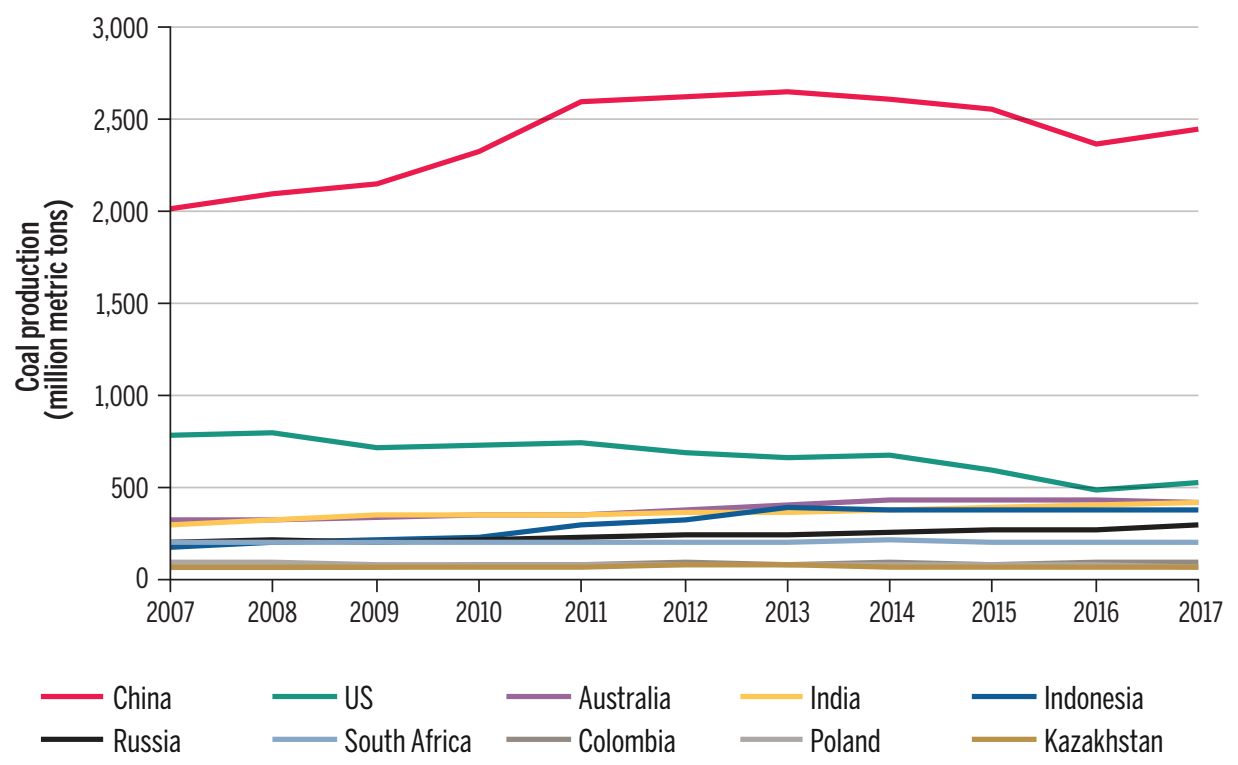

Figure 4. Coal production from 2007 to 2017 in the top ten coal-producing countries (in million metric tons) (BP, 2018).

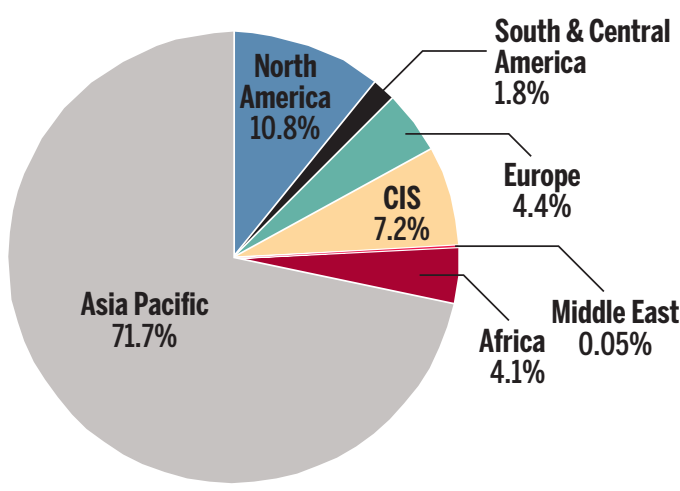

Figure 5. Shares of coal production in 2017 (BP, 2018). 


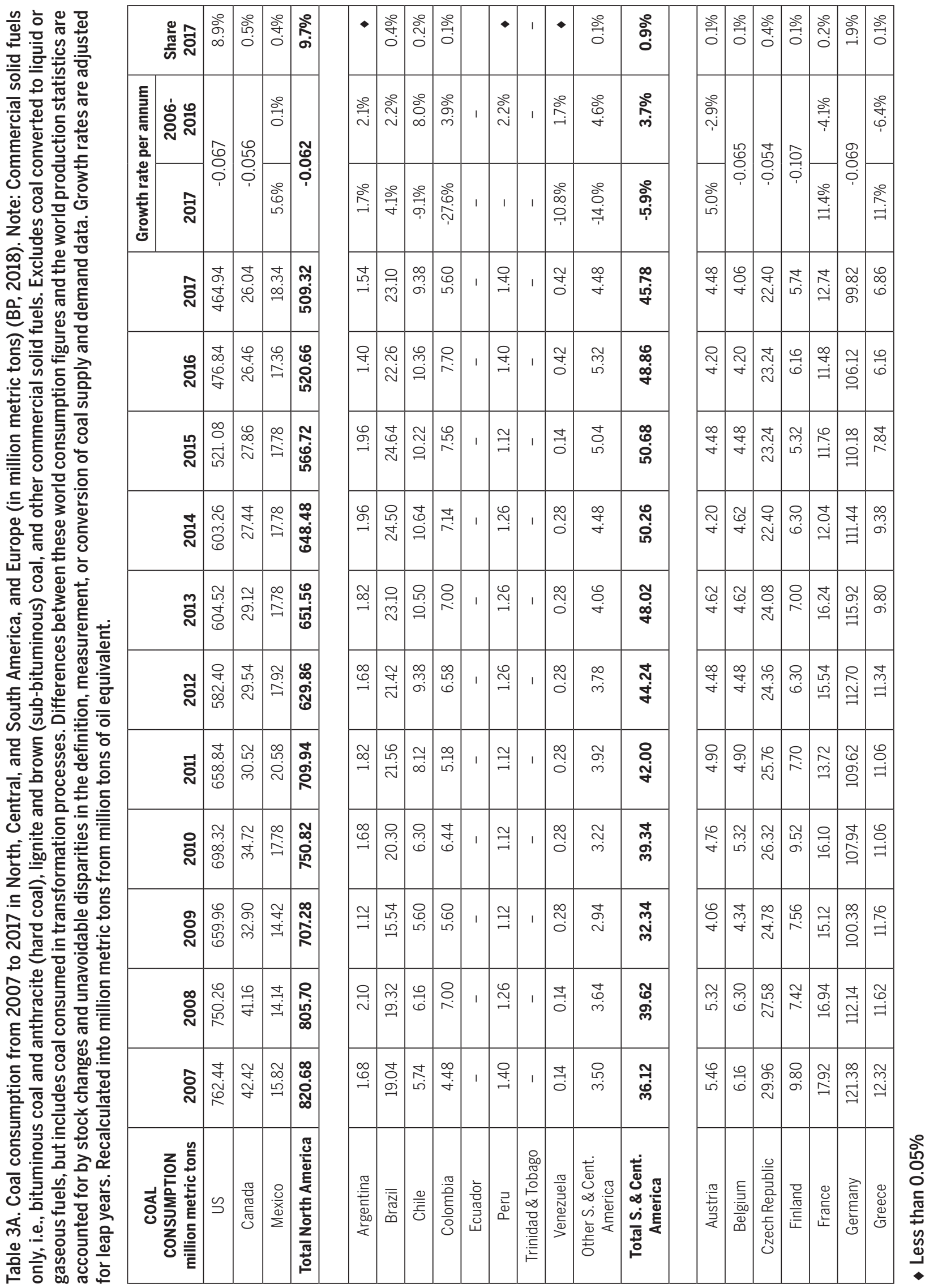




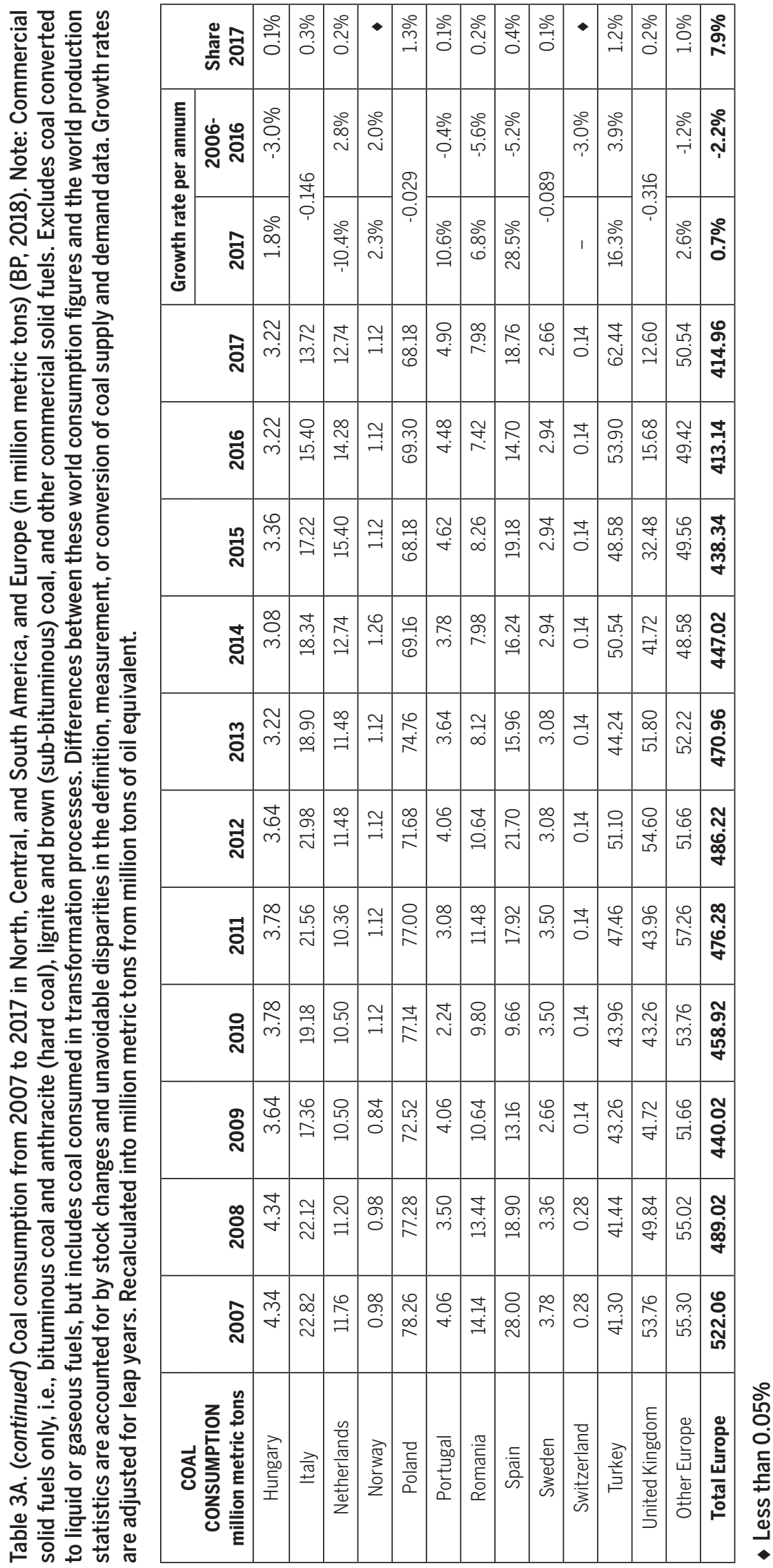




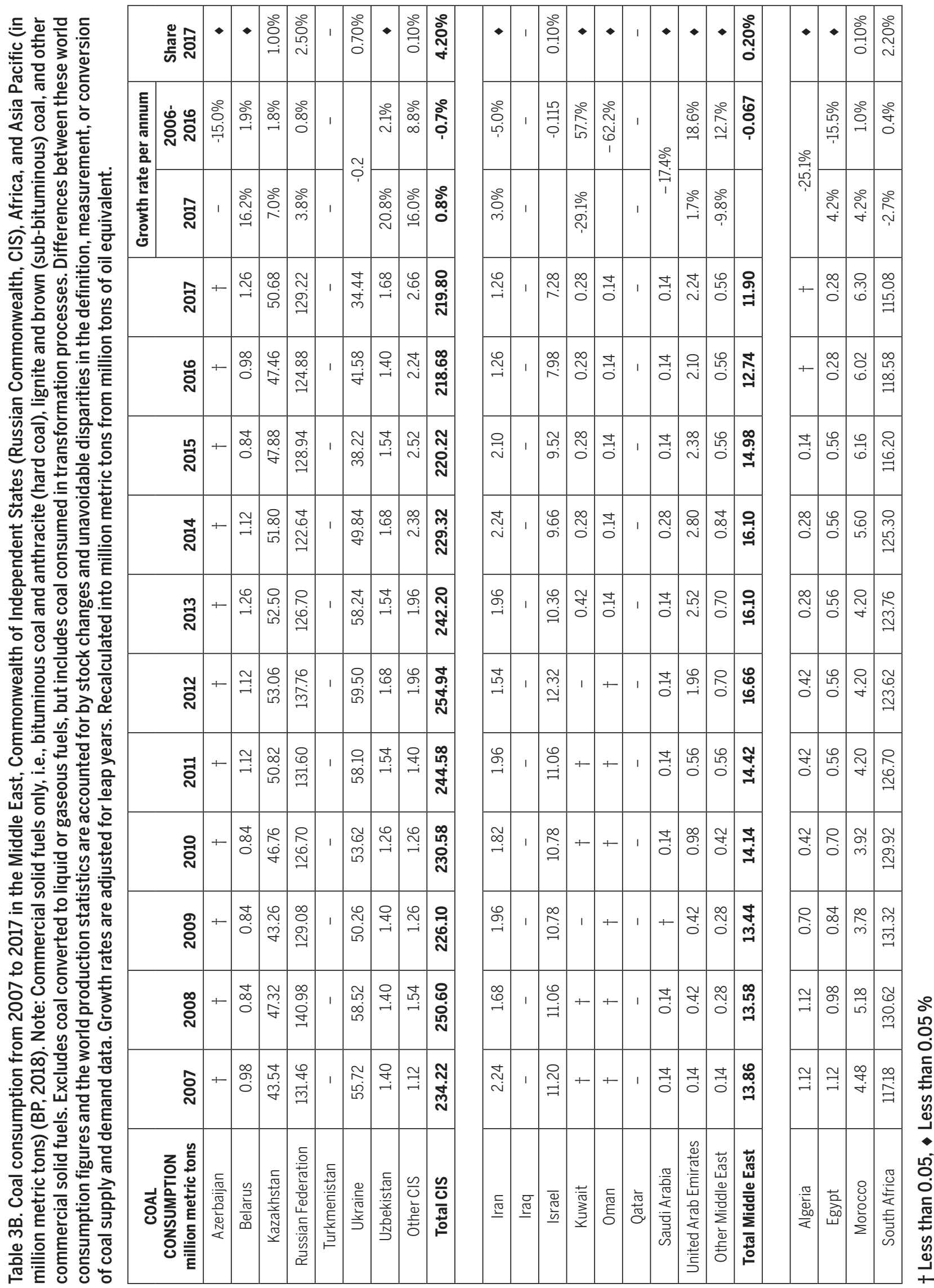




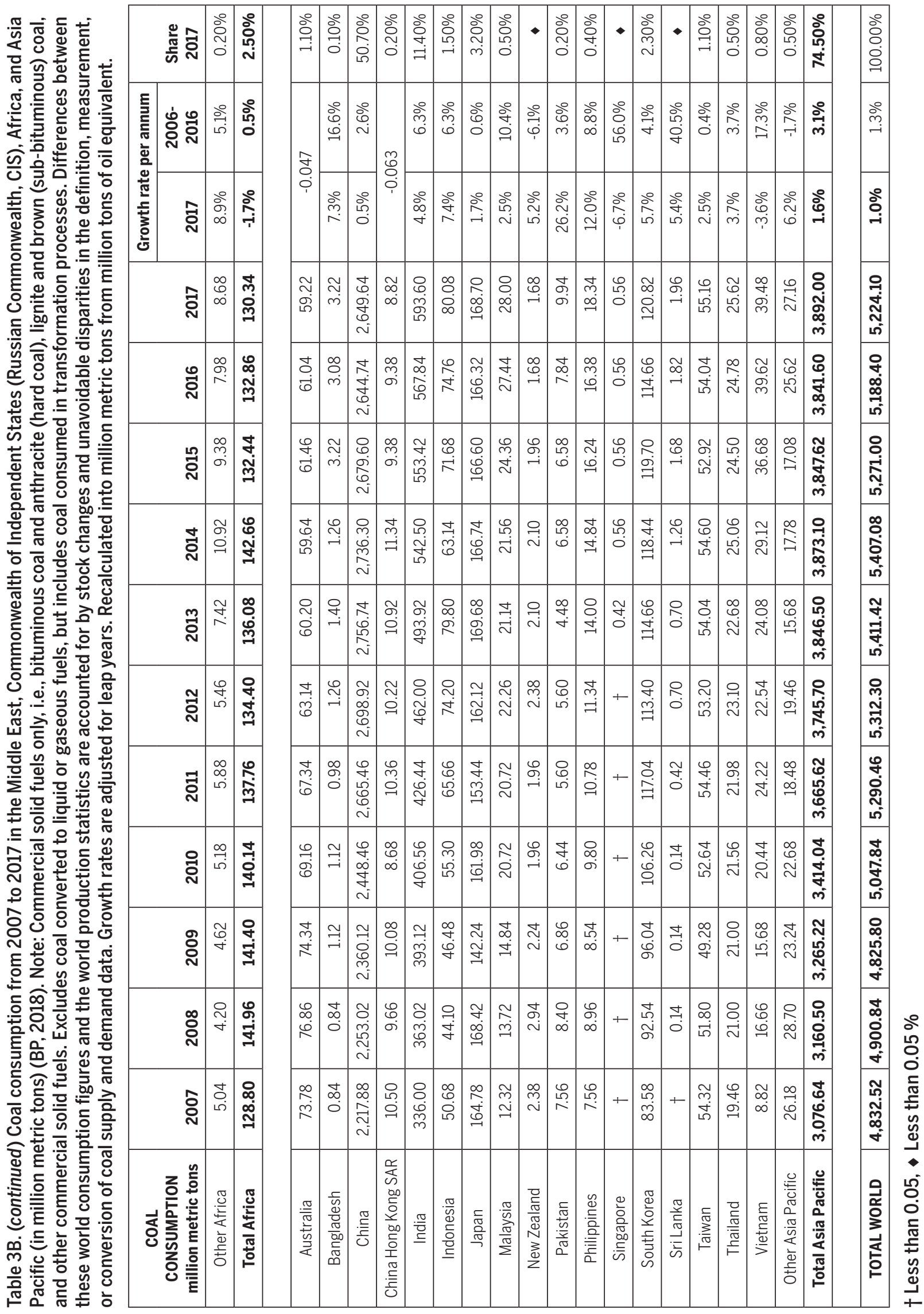




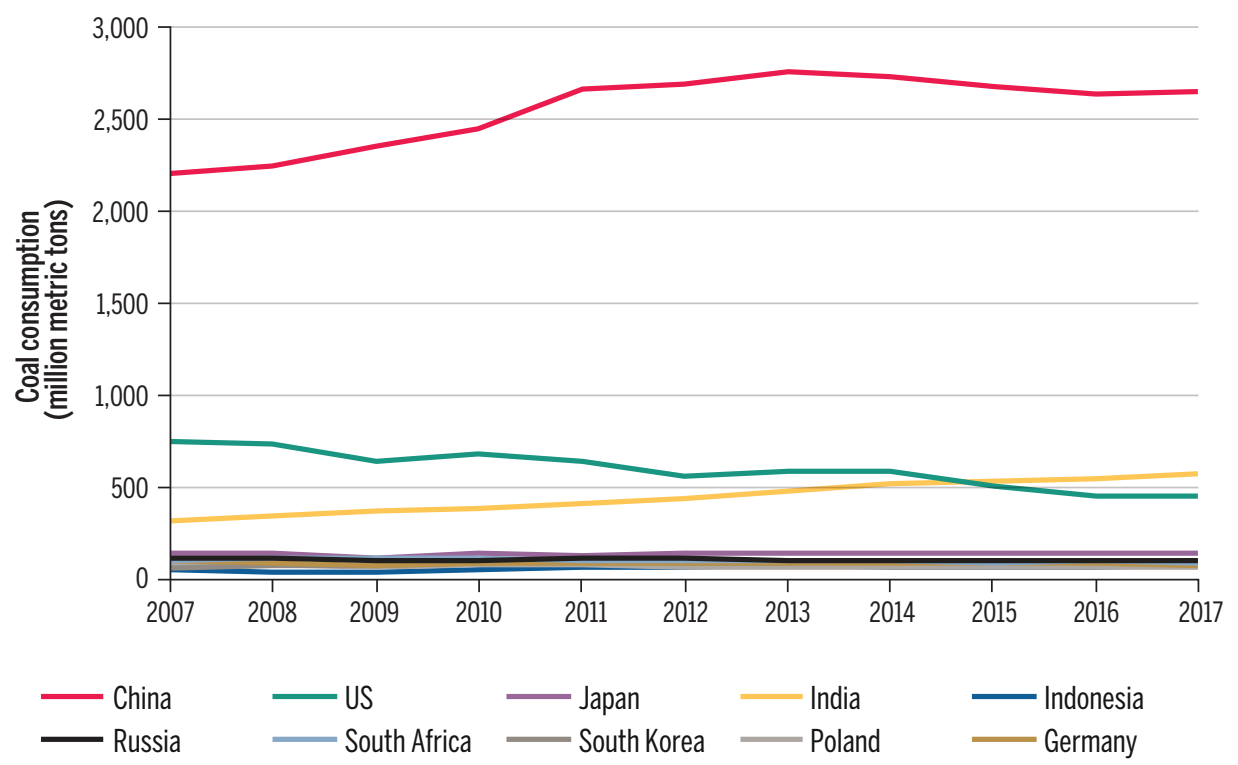

Figure 6. Coal consumption in the top ten coal-consuming countries from 2007 to 2017 in million metric tons (BP, 2018).

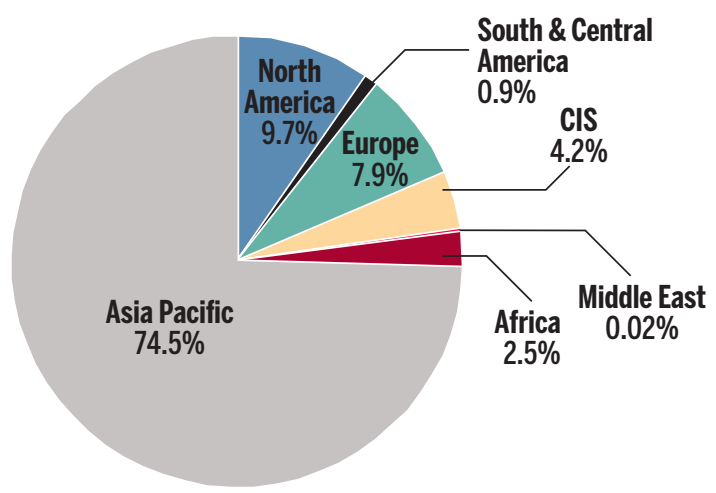

Figure 7. Shares of coal consumption in 2017 (BP, 2018). 

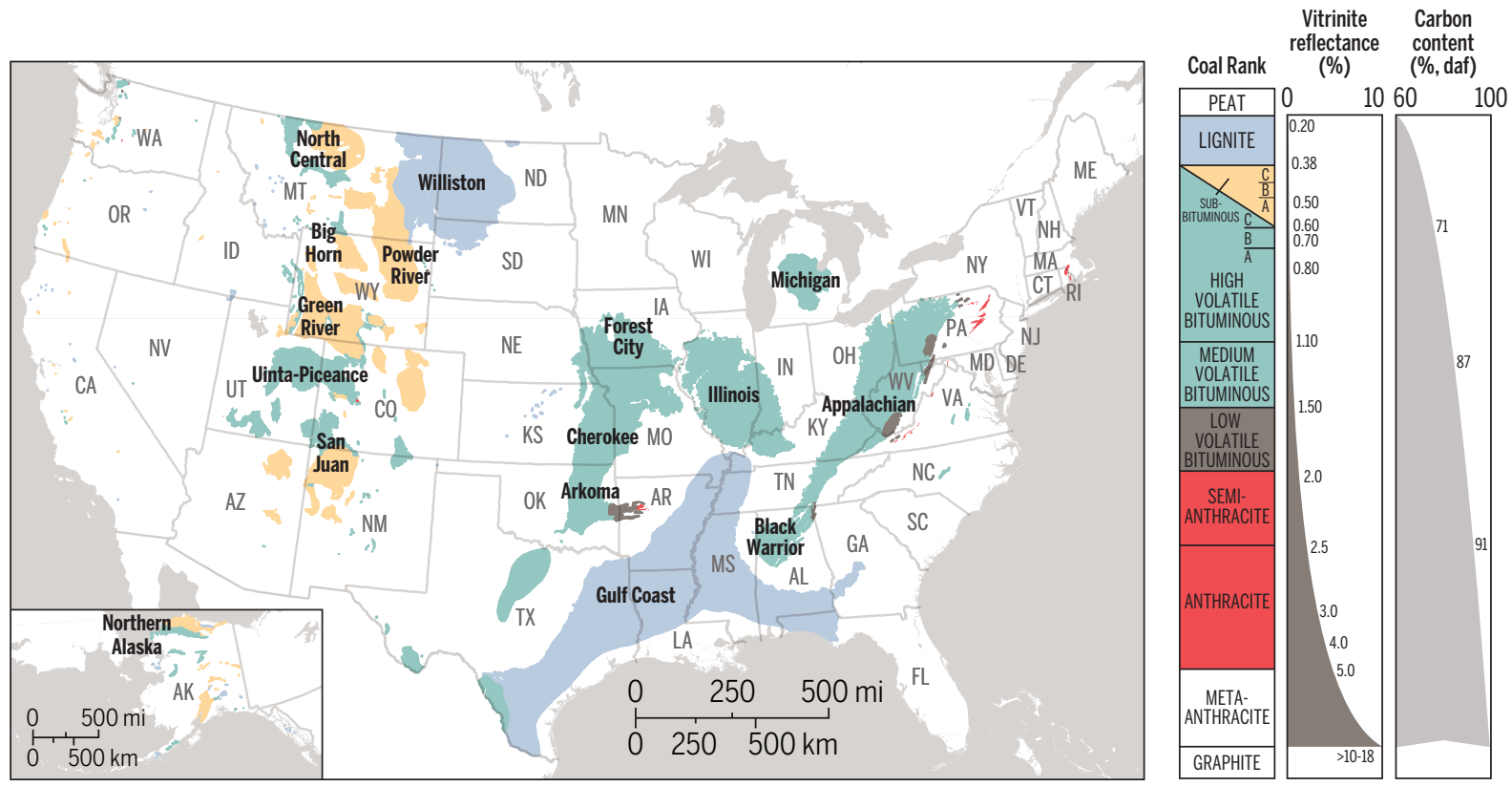

Figure 8. Map showing the coal basins of the United States and coal ranks and properties. Modified from EIA (2018a) and Tewalt and others (2008).

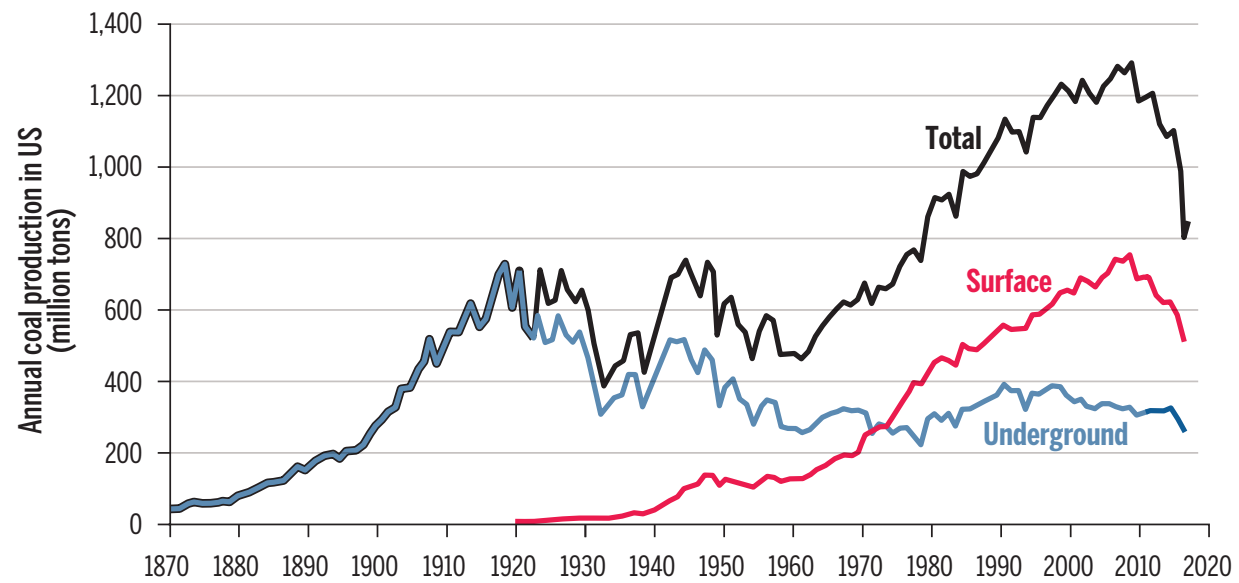

Figure 9. U.S. coal production from 1870 to 2017. Modified from Dan Plazak (written communication, Jan. 2019), and EIA (2018b). 


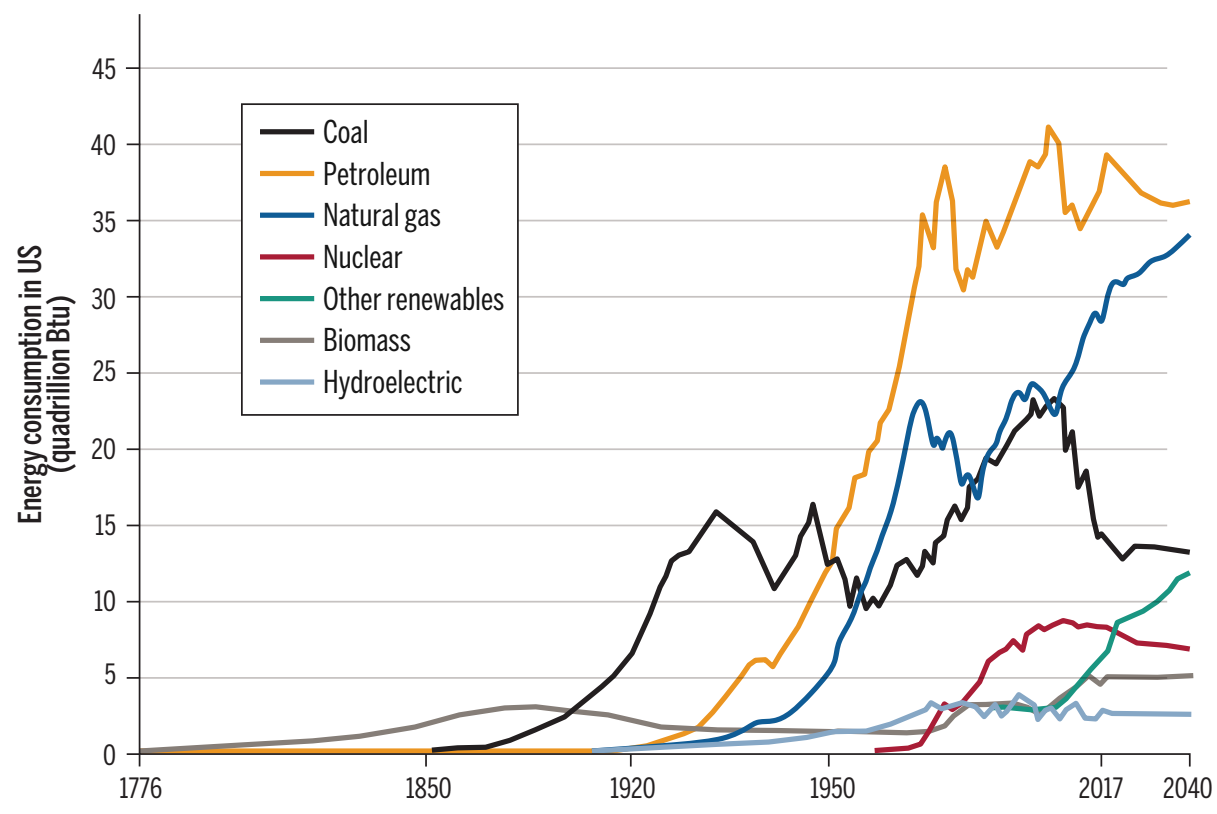

Figure 10. U.S. energy consumption. Data from EIA (2016, 2018c).

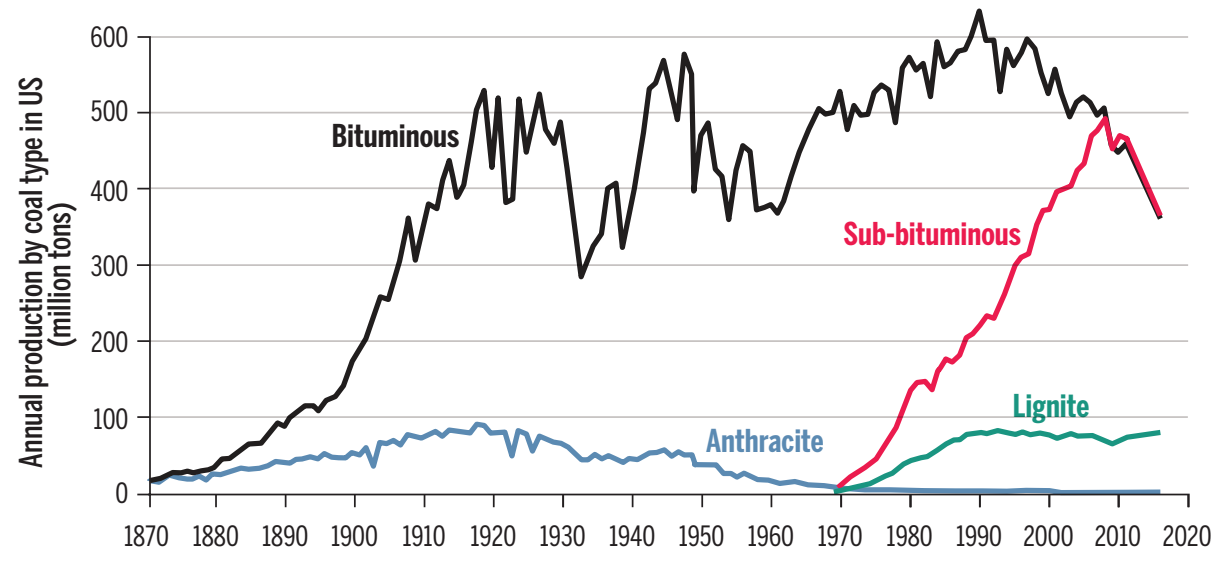

Figure 11. U.S. coal production by coal type from 1870 to 2016. Modified from Dan Plazak (written commun., Jan. 2019). 
overtook bituminous coal mining between 1843 and 1868. But because of the high demand for coal and the limited deposits of anthracite in the United States, bituminous coal, which occurs in much larger deposits, became the dominant contributor after 1869. At about that time, coal overtook wood as the United States's main energy source. Coal production then rapidly increased, peaking at 680 million short tons in 1918 (fig. 9) when new bituminous coal fields in Ohio, Indiana, Illinois, West Virginia, Kentucky, and Alabama were discovered. Some of these fields were small, and coal occurred at shallow depths, so coal companies developed surface mining methods, which increasingly contributed to production totals (fig. 9). In 1930, a rapid decrease in coal production was due to the drop-in demand during the Great Depression. During World War II (1941 to 1945), U.S. coal production bounced back and slightly exceeded pre-Depression levels. Then around 1960, during a natural gas and petroleum boom, coal production again declined (fig. 10). That decline was followed by a large increase in coal production from the early 1960 s through 2008 , in response to an increasing demand for energy. After a record high in 2008 of more than 1,063 million tons, production began to drop drastically, decreasing to about 660.9 million tons in 2016 (EIA, 2018d). Less expensive shale gas, increased demand for clean energy sources (fig. 10), and new EPA rules regarding emission limits from coalfired power plants and greenhouse gas pollution standards were factors responsible for this decline.

According to Energy Information Administration (EIA, 2018e), the United States produced 702 million metric tons of coal in 2017. We note that BP reports significantly lower U.S. production (519.82 million metric tons, Table 2; BP, 2018), which perhaps results from different estimating methods. In 2017, 14 percent of energy consumed in the United States was from coal, and coal accounted for 30 percent of U.S. electricity production (EIA, 2018f).

Because of the dominance of bituminous coal in U.S. coal production, trends of the total coal production (fig. 9) parallel changes in the coal of bituminous rank alone (fig. 11). Production of sub-bituminous coal began in the late 1960s and reached the production level of bituminous coal around 2007. The mining of lignite was also initiated around 1970; it gradually increased until 1990 and has since levelled off. Anthracite production was largest between 1910 and 1920, reaching almost 100 million tons, but since 1970 production has been minimal (fig. 11).

Of all the states, Wyoming produces the most coal; however, its 2018 production rate was much lower compared to its historic high in 2008 (fig. 12). West
Virginia, Pennsylvania, Illinois, and Kentucky, leading coal-producing states in the past, have also declined dramatically compared to their past maximum production. Similarly, Utah, New Mexico, Virginia, Colorado, Ohio, and Alabama all experienced greatly decreased coal production in relation to their historic highs. Some states (Texas, Indiana, Montana, and North Dakota) have maintained their levels of coal production, with some oscillations owing to, for example, long-term contacts or switching mining methods.

Although the most recent decline in U.S. coal production began around 2008, the number of coal mines has been decreasing since around 1981 (fig. 13). This decline has affected both surface and underground mining, as well as the number of coal processing plants. Environmental regulations, including the Coal Mine and Safety Act of 1969, the Surface Mining Control and Reclamation Act, and the Clean Water Act of 1977, contributed to the closing of some mines. These regulations also resulted in operators replacing or transforming older, smaller mines to larger mines. This became possible owing to the advent of larger, more efficient mining equipment and technologies. Mining costs also increased because of tighter regulations (EIA, 1992). More recently, more than half the mines operating in 2008 closed, a drop from 1,435 mines in 2008 to 671 mines in 2017 (fig. 14). As the demand for coal decreased, less efficient mines were the first to close, with most mine closures occurring in the Appalachian region. During that time, U.S. coal-fired power plants also declined in number; of 606 coal-burning power plants in 2007, 359 remained in 2017, with the rest closing because of aging infrastructure and stiffer environmental guidelines (EIA, 2018f).

In 2017, about 63 percent of electricity generated in the United States came from fossil fuels. Coal accounted for 39 percent in 2014, 33 percent in 2015, 30.4 percent in 2016, and 29.9 percent in 2017 (EIA, 2018j). In comparison, electricity generated from coal in Indiana accounted for 70 percent in 2017 (EIA, 2018h).

Employment in the coal mining industry peaked around 1920 with close to 900,000 workers (fig. 15). At present in the United States, employment is at its lowest point in coal production history, at about 53,000 in 2018 (EIA, 2018d). The number of fatalities in the U.S. coal mining industry declined from more than 3,000 a year (1907) to fewer than 100 annually in recent years (fig. 16). The decline after 1970 was primarily due to increased regulations and safety in the mines, a direct effect of the Coal Mine Health and Safety Act of 1969.

Before 1955, the number of people employed in the coal industry paralleled coal production trends, but later, between 1955 and 2008, employment depended on other factors such as technological advances and 


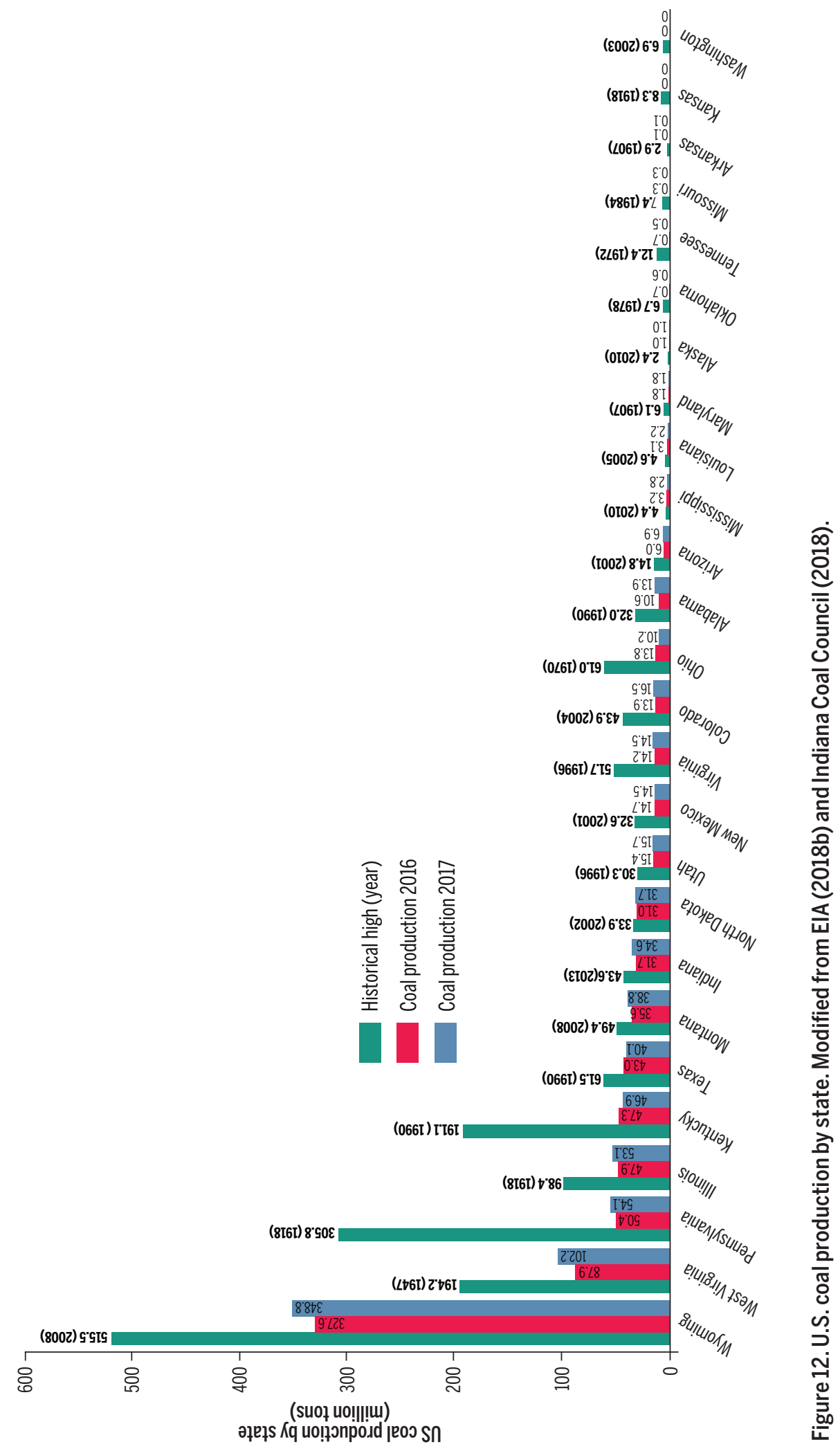




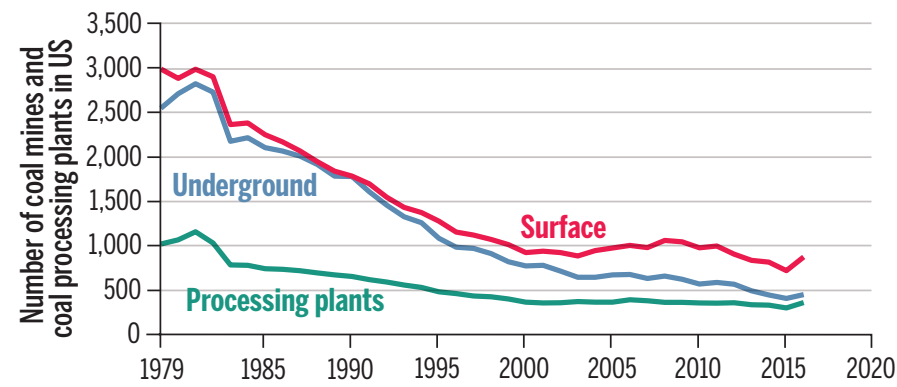

Figure 13. Number of U.S. coal mines and coal processing plants from 1979 to 2016. Modified from U.S. Department of Labor (2017).

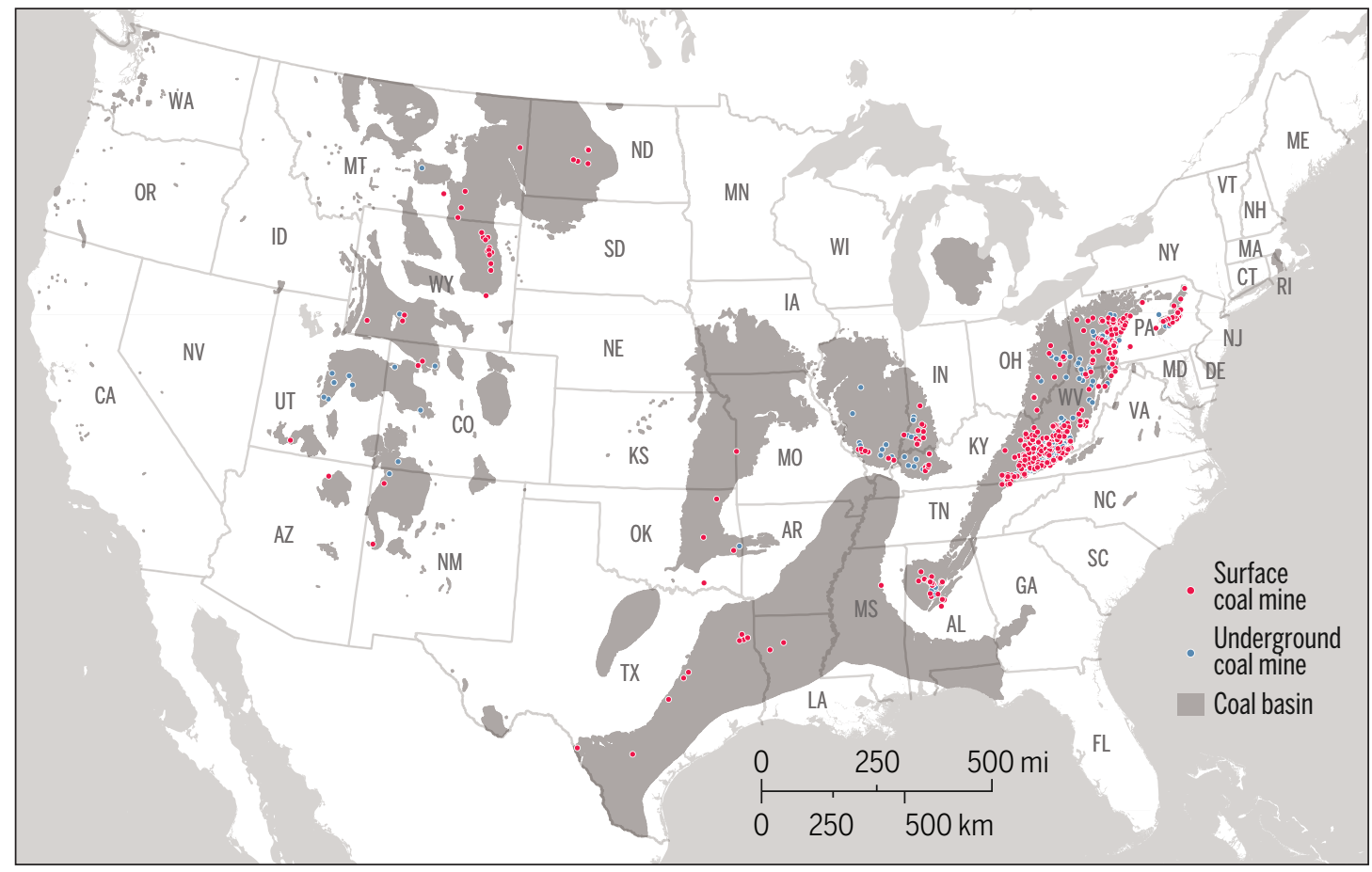

Figure 14. Active U.S. coal mines in 2017 (EIA, 2018i). 


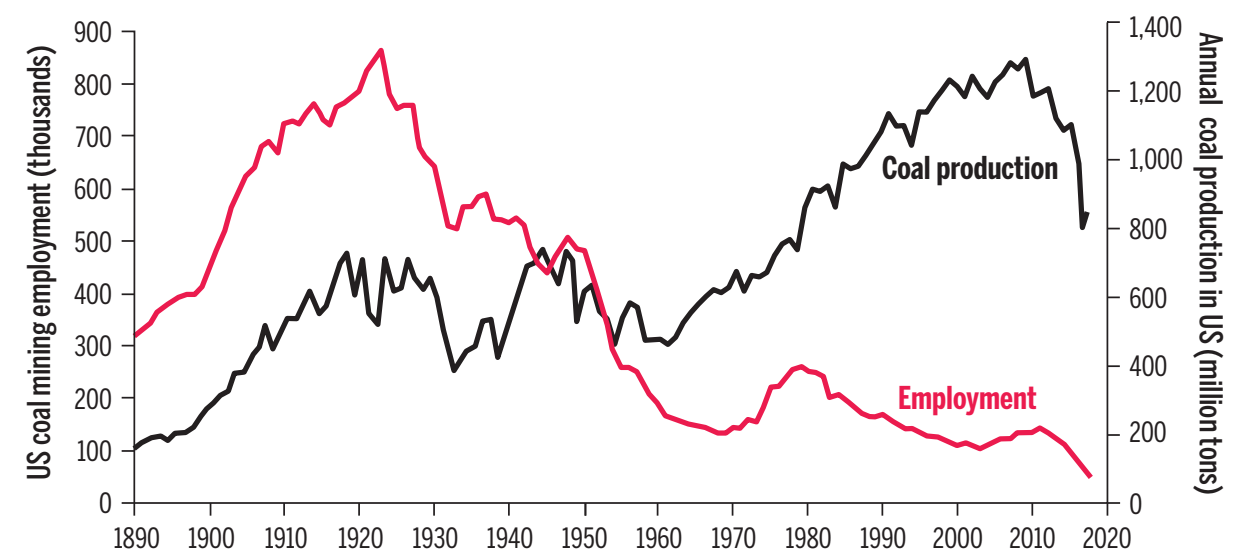

Figure 15. U.S. coal production and coal mining industry employment from 1890 to 2018. Employment data modified from Dan Plazak (written commun., Jan. 2019) and Federal Reserve Board of St. Louis (2018). Beginning in 1973, the data includes office workers. Coal production modified from Dan Plazak (written commun., Jan.2019), and EIA (2018b).

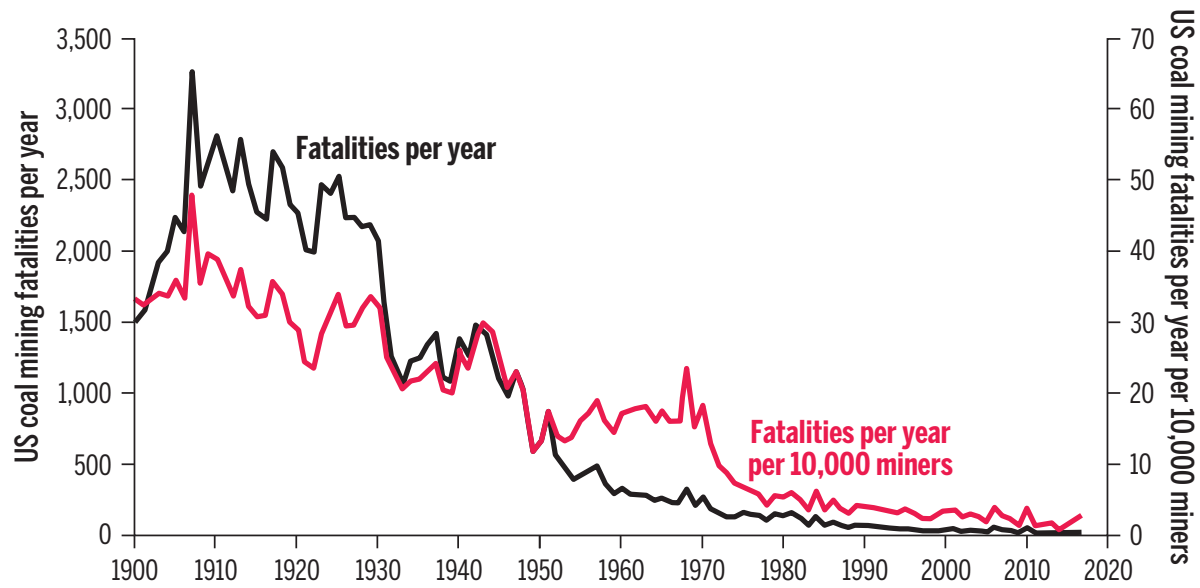

Figure 16. U.S. coal mining fatalities from 1900 to 2017. Data from U.S. Department of Labor (2017). 


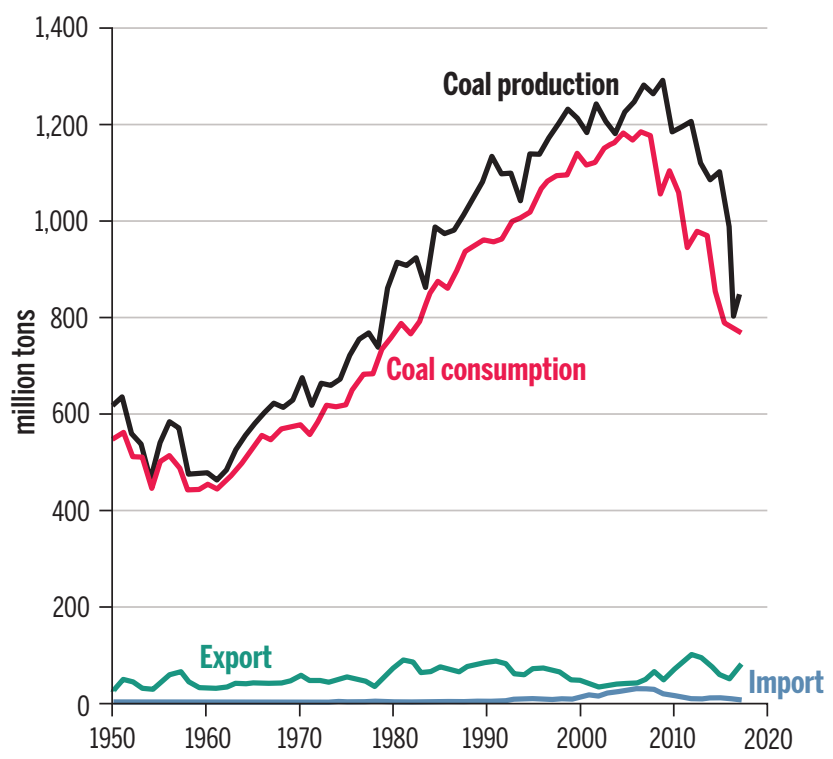

Figure 17. U.S. coal production, consumption, export, and import. Data from EIA (2018g).

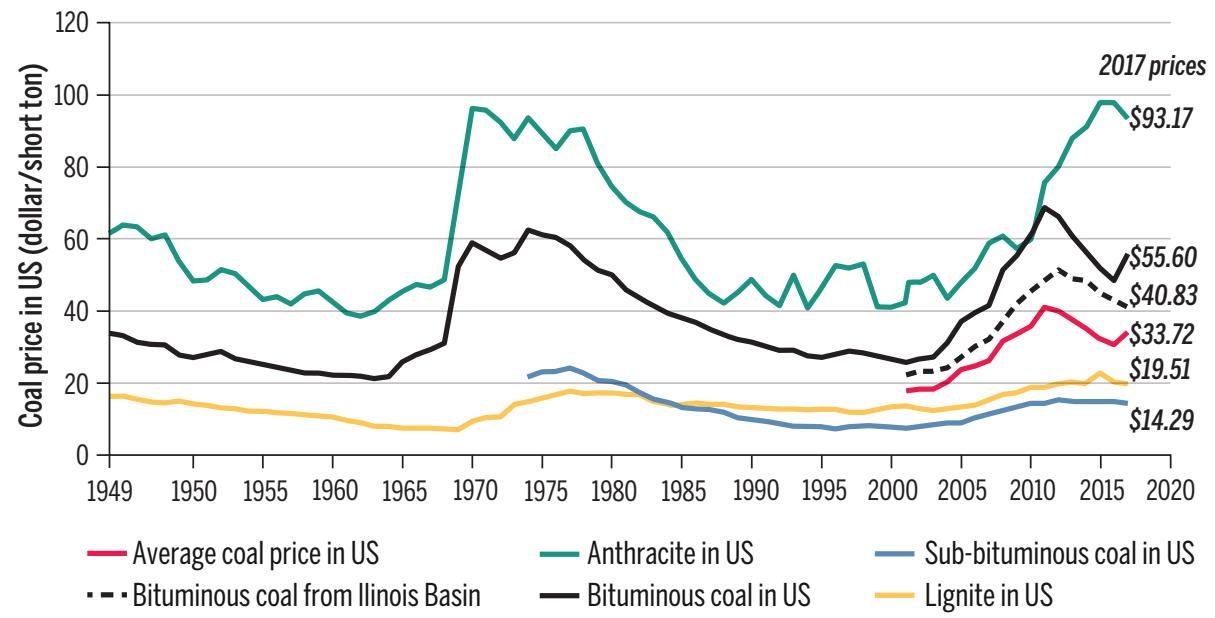

Figure 18. U.S. coal prices from 1949 to 2017. Modified from EIA (2011) and EIA (2018b, j).

productivity. Since 2008, the decline in employment again correlates with the decline in coal production and consumption (figs. 15, 17) as a response to the increased production of cheap natural gas and increasing public demand for clean energy (fig. 10). However, between 2016 and 2018 about 1,200 new jobs in coal mining industry were added, an increase of about 2.4 percent compared to 2016 (EIA, 2018i).

Despite its large coal reserves and high production total of 702 million tons in 2017 (EIA 2018g), the United States imported about 7.2 million short tons of coal that year, because some coal-burning power plants along the Atlantic and Gulf Coasts could buy imported coal cheaper than domestic coal (fig. 17). Imported coal came primarily from Colombia (78 percent) and Canada
(11 percent). The remaining 11 percent was from 13 other countries (EIA, 2018g).

The United States is a net coal exporter (fig. 17). Exports of American coal reached a record high of about 115 million tons in 2012, equal to about 12 percent of U.S. total coal production (EIA, 2018f). Coal exports decreased by half between 2012 and 2016 to about 55 million tons, but in 2017 increased again to about 88 million tons, about 13 percent of U.S. coal production. The United States exports mostly metallurgical coal used for steel production and steam coal for electricity generation. The biggest importers of U.S. coal in 2017 were India (11.8 percent), South Korea (9.7 percent), the Netherlands (9.7 percent), Japan (7.9 percent), and Brazil (7.8 percent) (EIA, 2018f). 
Coal prices also fell since 2008, except for anthracite coal, which reached an average of $\$ 93.17$ per short ton in 2017 (fig. 18). The average price of U.S. coal was $\$ 55.60$ per short ton; 2019 prices in real dollar terms are not higher than those 40 years earlier.

In 2016, the new U.S. government administration promised to help the U.S. coal industry and coal-fired power plants, the biggest buyer of American coal, and bring coal-related jobs back. Between 2016 and 2018, about 1,200 new jobs in coal mining industry were added, an increase of about 2.4 percent, compared to 2016 (EIA, 2018d). The administration was also considering new greenhouse gas emission rules for power plants that would make it easier for states to keep coal-fired facilities operational. The plan would replace the previous administration's approach, which proposed a steady retirement of coal plants. Coal mining is an industry in transition as new energy sources, new technologies, and policies continually reshape the energy landscape. With increased competition from other sources of energy and a steady decline in the number of coal-fired power plants, the U.S. coal industry faces a future that is difficult to predict.

\section{STATE-SCALE CHANGES IN COAL MINING: INDIANA}

Indiana has been a coal mining state for close to 200 years and has experienced its own changes in the coal mining industry. Coal has been mined in Indiana since its discovery along the banks of the Wabash River in 1736 (Mastalerz and others, 2009). Records show that underground mining began in Indiana in the early 1830 s, with production increasing steadily until 1910 (fig. 19). Around 1920, the demand for coal decreased, which, together with the declining marketability of Illinois Basin coal, resulted in a drop in production from underground operations (fig. 20). The relatively low heating value and high sulfur content of Indiana coal (compared to Eastern coal), as well as the relatively high salaries paid to unionized miners in Indiana and Illinois were among the factors that limited development of underground mining in Indiana during that period.

The events of World War I resulted in a brief doubling of coal production in Indiana. However, after 1923, newer non-union coal fields (in, for example, West Virginia) attracted consumers in Chicago as well as in Indiana and Illinois, causing a dramatic decline in Indiana's underground coal production to levels far below those just prior to the war (figs. 19 and 20). By the 1960s, limited resources of thick and laterally extensive coals needed for underground mining precluded the development of underground mining in Indiana, and, since then, surface mining has dominated the industry (fig. 19).

The implementation of the Clean Air Act of 1970 and the introduction of sulfur-dioxide emissions standards for coal-fired utility boilers by the U.S. Environmental Protection Agency in 1971 affected both surface and underground mining in the entire Illinois Basin (fig. 21). Because of the relatively high sulfur content of Illinois Basin coals, including Indiana coals, many utilities opted to switch to low-sulfur Powder River Basin coals from Wyoming rather than install scrubbers to reduce emissions (EIA, 1992). In addition, the Surface Mining Control and Reclamation Act of 1977 increased the cost of coal production from surface mines. Although these environmental regulations and their consequences affected Indiana's mining, increasing energy demand and the installation of gas scrubbers to reduce emissions by utilities (in response to the 1990 Clean Air Amendments) contributed to the general upward trend in coal production till 1988 (fig. 21). From 1988 to 1994, the industry experienced a rapid drop in coal production; this was followed by a rapid increase, owing to increased production from underground mines in Indiana (figs. 19, 20). Surface mining gradually declined during that period. In 2017, coal production declined in Indiana. However, in 2018 the state produced a total of 33.512 million tons of coal (Indiana Coal Council, 2018) - evidence that Indiana's coal production was not dramatically affected by the shale gas boom. As expected, trends in Indiana coal production roughly echo those of Illinois and western Kentucky (fig. 21).

Approximately 57 billion tons of unmined coal reserves remain in Indiana, of which nearly 17 billion tons can be mined using current technology (Mastalerz and others, 2009). Of the mineable reserves, about 88 percent is recoverable by underground mining and 12 percent by surface mining methods. In 2018, 33.512 million tons of coal were produced in Indiana-16.5 million from underground mines and 17.0 million tons from surface mines. As of 2018, ten surface and five underground coal mines were operating in Indiana (Indiana Coal Council, 2018) (fig. 22), marking a declining trend in the number of surface mines since 2009 (fig. 23). In 2018, more than 50 percent of total energy and 70 percent of electricity in Indiana comes from coal (EIA, 2018h).

The surface mines having the largest coal production in Indiana are Bear Run Mine (Sullivan County) and Wild Boar Mine (Warrick County), both Peabody operations (Table 4). Out of five underground mines in operation in Indian in 2018, the largest were Gibson South Mine (Gibson County Coal) and Oaktown Mine (Sunrise Coal) (Table 5). 


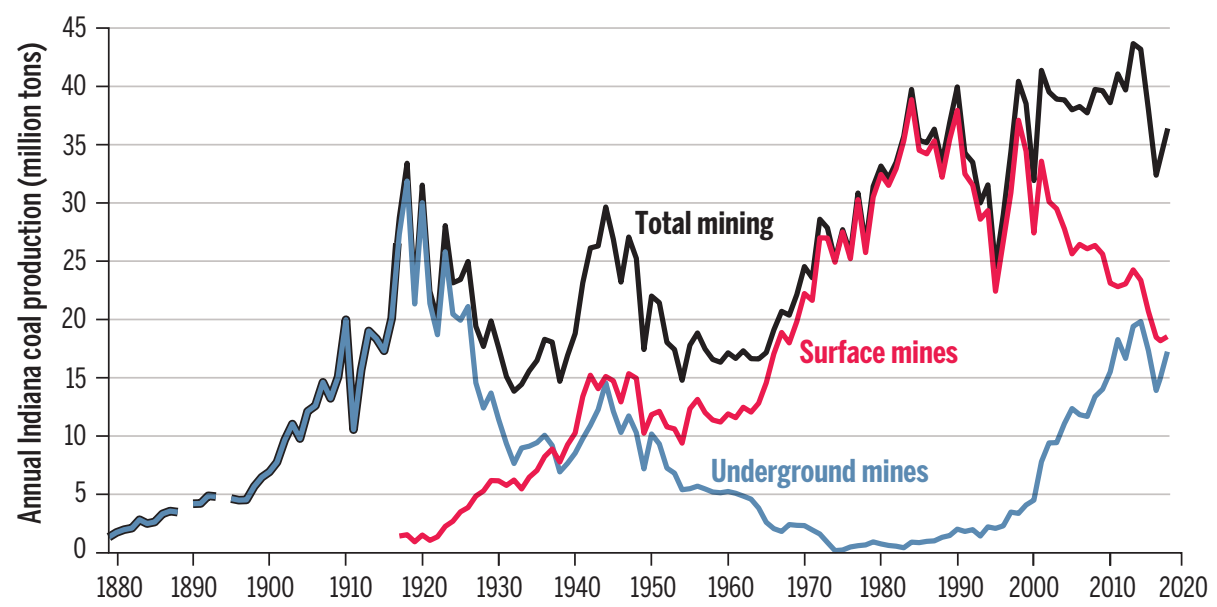

Figure 19. Indiana coal production from 1879 to 2018. Data from U.S. Bureau of Mines (2018; data through 1972); Indiana Bureau of Mines (1973-1997); from Indiana Coal Council (1998).

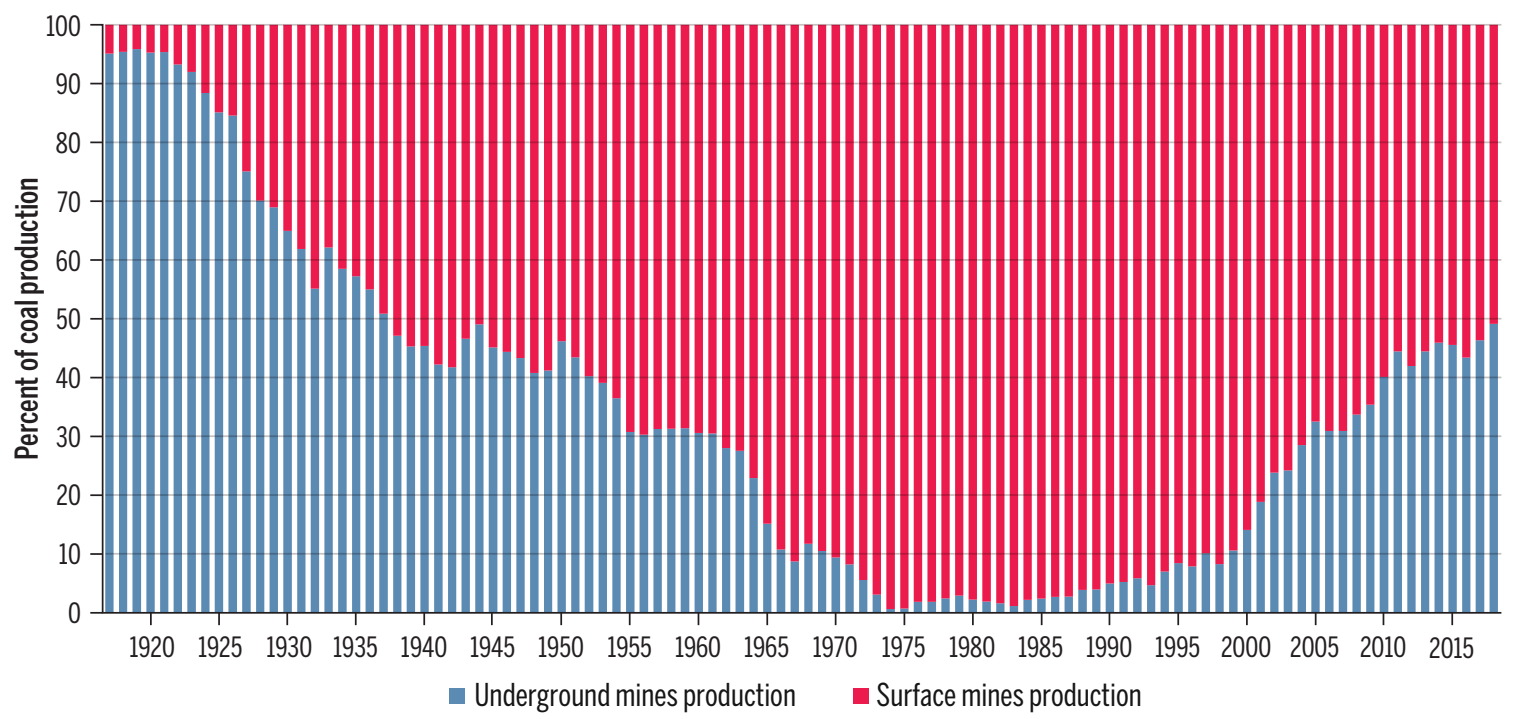

Figure 20. Indiana coal production from underground and surface mines in percentages of contribution. Data from U.S. Bureau of Mines (2018; data through 1972); Indiana Bureau of Mines (1973-1997); Indiana Coal Council (1998).

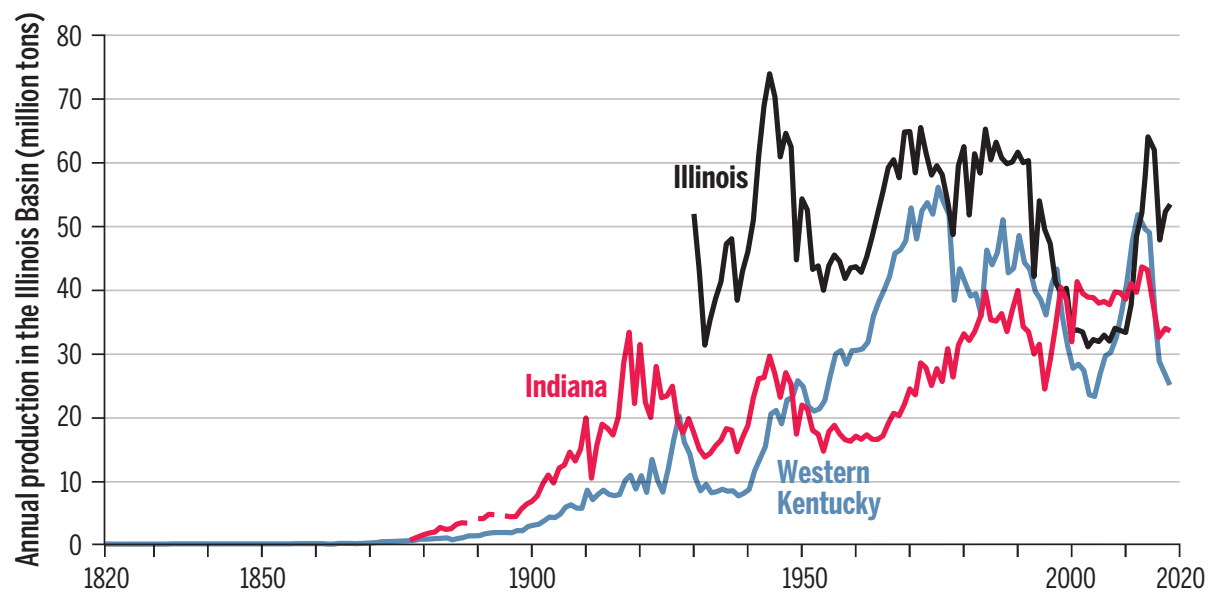

Figure 21. Illinois Basin coal production from 1820 to 2018. Indiana data: U.S. Bureau of Mines (2018; data through 1972), Indiana Bureau of Mines (1973-1997), Indiana Coal Council (1998); Illinois data: ElA (2018b); Kentucky data: Kentucky Geological Survey (1790-2014), Kentucky Quarterly Coal Report (2018; data from 2015). 


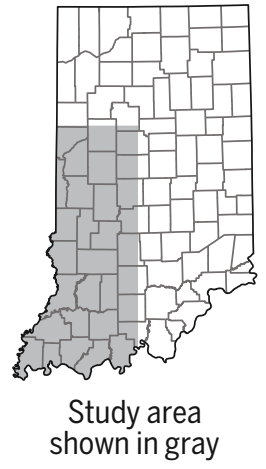

Active surface mine

Active underground mine

Mined out by surface mining

Mined out by underground mining

Extent of the Pennsylvanian

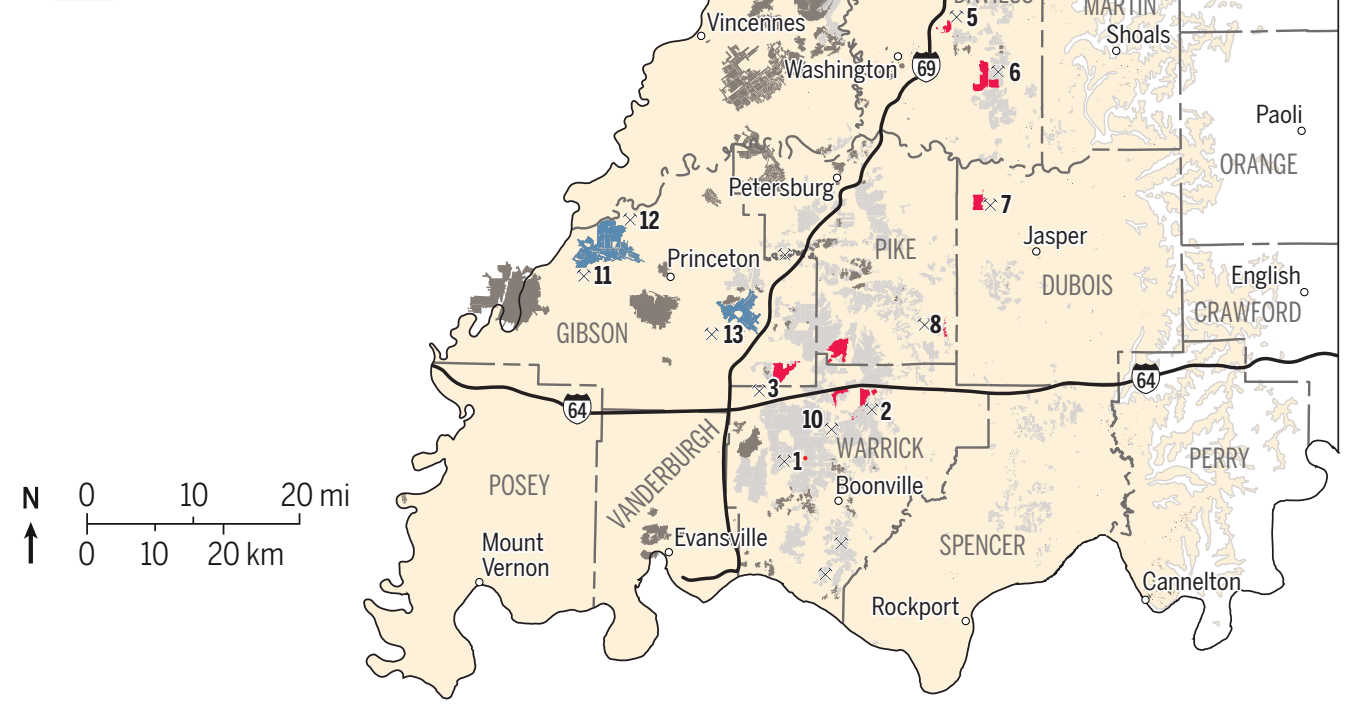

Figure 22. Location of active coal mines and mined-out coal areas in Indiana as of 2018. Numbers on the map correspond to Tables 1 and 2. 


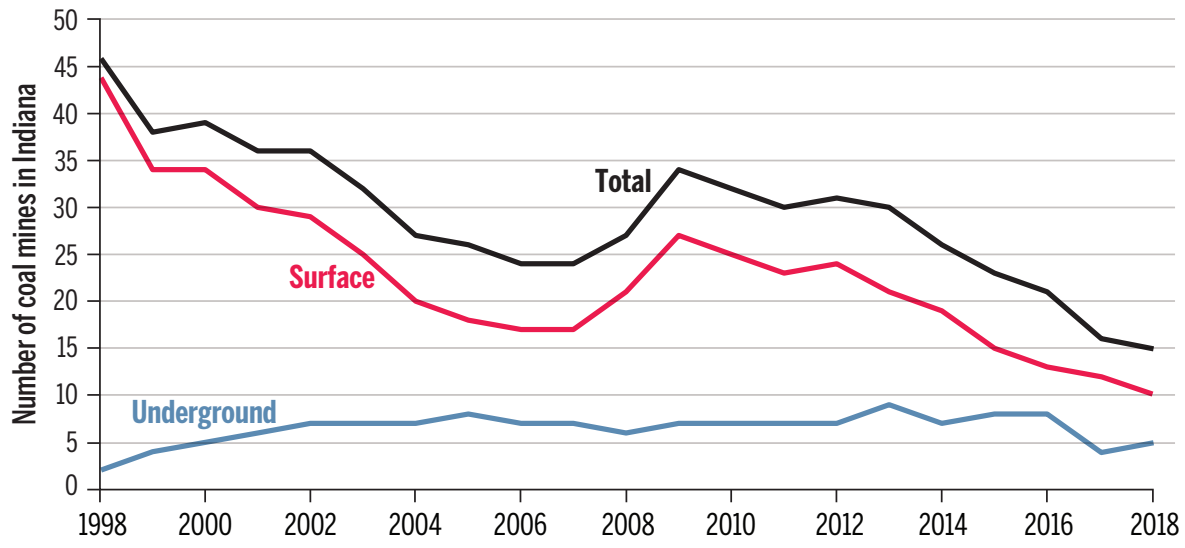

Figure 23. Number of Indiana coal mines from 1998 to 2018. Data from Indiana Coal Council (2018).

Table 4. Active surface coal mines in Indiana as of 2018. Map numbers on Figure 22. Data from Indiana Coal Council (2018).

\begin{tabular}{|c|c|c|c|c|}
\hline \multicolumn{5}{|c|}{ INDIANA SURFACE COAL MINE PRODUCTION IN 2018 } \\
\hline Operator & Map number & Mine & Production (tons) & County \\
\hline Liberty Mine, LLC & 1 & Liberty Mine & $1,627,647$ & Warrick \\
\hline \multirow{2}{*}{$\begin{array}{c}\text { Peabody Midwest } \\
\text { Mining, LLC }\end{array}$} & 2 & Wild Boar & $2,487,892$ & Warrick \\
\cline { 2 - 5 } & 3 & Somerville South & $1,971,905$ & Gibson \\
\cline { 2 - 5 } & 4 & Bear Run & $6,911,825$ & Sullivan \\
\hline \multirow{3}{*}{ Solar Sources, Inc. } & 5 & Antioch & $1,309,960$ & Daviess \\
\cline { 2 - 5 } & 7 & Cannelburg & 765,557 & Daviess \\
\hline Sun Energy Group, LLC & 8 & Shamrock & $1,217,512$ & Dubois \\
\hline Sunrise Coal, LLC & 9 & Hillsmeyer & 156,631 & Clay \\
\hline United Minerals, Inc. & 10 & Ace in the Hole & 351,967 & Warrick \\
\hline \multicolumn{7}{|l|}{ TOTAL INDIANA SURFACE MINE PRODUCTION 2017 } & 246,566 & $\mathbf{1 7 , 0 4 7 , 1 9 2}$ \\
\hline
\end{tabular}

Table 5. Active underground coal mines in Indiana as of 2018. Map numbers on Figure 22. Data from Indiana Coal Council (2018).

\begin{tabular}{|c|c|c|c|c|}
\hline \multicolumn{5}{|c|}{ INDIANA UNDERGROUND COAL MINE PRODUCTION IN 2018 } \\
\hline Operator & Map number & Mine & Production (tons) & County \\
\hline \multirow{2}{*}{ Gibson County Coal Co. } & 11 & Gibson South & $6,951,510$ & Gibson \\
\cline { 2 - 5 } & 12 & Gibson North & 923,743 & Gibson \\
\hline $\begin{array}{c}\text { Peabody Midwest } \\
\text { Mining, LLC }\end{array}$ & 13 & Francisco & $2,248,274$ & Gibson \\
\hline \multirow{2}{*}{\begin{tabular}{c} 
Sunrise Coal, LLC \\
\cline { 2 - 5 }
\end{tabular}} & 14 & Carlisle & 370,404 & Sullivan \\
\hline \multicolumn{2}{|c|}{ TOTAL INDIANA UNDERGROUND MINE PRODUCTION 2017 } & \multicolumn{2}{|c|}{$\mathbf{1 6 , 4 6 5 , 6 8 3}$} \\
\hline
\end{tabular}




\section{CONCLUSIONS}

Despite having the world's largest reserves of coal, the U.S. coal industry is experiencing challenging times and faces an uncertain future. Currently containing 24.2 percent of the world's reserves, the U.S. contribution to world coal production and consumption is 10 percent and 9 percent, respectively. Although the coal mining industry has experienced considerable variations over its 200 year history in the United States, previous periods of decline were relatively short lived and were followed by the rejuvenation of the industry in response to increasing demands for energy. The most recent decline of the coal mining industry since 2008, manifested by drop in coal production, number of mines, and employment, may be of a more permanent nature. Over the last decade, not only has coal faced competition from other energy sources (fig. 10), but a growing understanding of the environmental problems stemming from the use of coal and stricter environmental regulations have contributed to the retirements of many coal-fired power plants.

Even with the recent changes in the U.S. mining industry, in 2017, 14 percent of energy consumed in the United States was generated from coal, and coal accounted for 30 percent of U.S. electricity production. Some states continue to rely heavily on coal; in Indiana more than 50 percent of the total energy and 70 percent of electricity comes from coal.

A recent decline in coal production, although experienced by the majority of coal-producing states, has affected individual states and coal basins differently. Indiana, in contrast to Illinois and western Kentucky, has been able to maintain its coal production at or above 30 million tons over the last two decades, partly because of increasing contributions from underground mines, which have compensated for the decline in surface mining. In 2018, coal production from underground mines in Indiana (17,047,192 tons) closely approached surface mine production of $16,465,683$ tons. But even in Indiana, in today's energy climate, the coal industry needs technical innovations and new ideas to successfully continue forward and to play an important role in the U.S. economy.

\section{REFERENCES}

BP, 2018, Statistical review of world energy, 67th ed.: BP website, 53 p., accessed January 3, 2019, at URL https://www. bp.com/content/dam/bp/business-sites/en/global/corporate/ pdfs/energy-economics/statistical-review/bp-stats-review2018-full-report.pdf.
Brownfield, M. E., Steinhouer, D. W., Povarennykh, M. Y., Eriomin, I., Shpirt, M., Meitov, Y., Sharova, I., Goriunova, N., and Zyrianova, M. V., 2001, Coal quality and resources of the Former Soviet Union-an ArcView project: U.S. Geological Survey Open-File Report 01-104, accessed Dec. 15, 2019, at URL https://pubs.usgs.gov/of/2001/ofr-01-104/ fsucoal $/ \mathrm{html} / \mathrm{readme} . \mathrm{htm}$.

Energy Information Administration, 1992, The U.S. coal industry, 1970-1990-two decades of change: Energy Information Administration, Office of Coal, Nuclear, Electric and Alternative Fuels, U.S. Department of Energy, DOE/ EIA-0559, 116 p.

Energy Information Administration (EIA), 2011, Annual energy review 2011: U.S. Energy Information Administration, Office of Coal, Nuclear, Electric and Alternative Fuels, U.S. Department of Energy, accessed Feb. 13, 2019, at URL https://www.eia.gov/totalenergy/data/annual/pdf/aer.pdf.

Energy Information Administration (EIA), 2016, Annual energy outlook: U.S. Energy Information Administration, Office of Coal, Nuclear, Electric and Alternative Fuels, U.S. Department of Energy, accessed Feb. 15, 2019, at URL https:// www.eia.gov/outlooks/aeo/pdf/0383(2016).pdf.

Energy Information Administration (EIA), 2018a, U.S. coal reserves: U.S. Energy Information Administration, Office of Coal, Nuclear, Electric and Alternative Fuels, U.S. Department of Energy, accessed Feb. 13, 2019, at URL https://www.eia.gov/coal/reserves/.

Energy Information Administration (EIA), 2018b, U.S. coal data: U.S. Energy Information Administration, Office of Coal, Nuclear, Electric and Alternative Fuels, U.S. Department of Energy, accessed Feb. 13, 2019, at URL https://www.eia. gov/coal/data.php.

Energy Information Administration (EIA), 2018c, Annual energy outlook 2018: U.S. Energy Information Administration, Office of Coal, Nuclear, Electric and Alternative Fuels, U.S. Department of Energy, accessed Feb. 1, 2019, at URL https://www.eia.gov/outlooks/aeo/pdf/AEO2018.pdf (accessed 1 February 2019).

Energy Information Administration (EIA), 2018d, 2018 Annual coal report: U.S. Energy Information Administration, Office of Coal, Nuclear, Electric and Alternative Fuels, U.S. Department of Energy, accessed Feb. 5, 2019, at URL https://www.eia.gov/coal/annual/.

Energy Information Administration (EIA), 2018e, Coal prices 2008-16: U.S. Energy Information Administration, Office of Coal, Nuclear, Electric and Alternative Fuels, U.S. Department of Energy, accessed Feb. 13, 2019, at URL https://www.eia.gov/coal/data/browser/\#/ topic/29?agg=1,0\&geo $=$ g $0000000000003 \mathrm{vu} \&$ fre $\mathrm{q}=\mathrm{A} \& \operatorname{star} \mathrm{t}=2008 \& \mathrm{end}=2016 \&$ ctype $=$ map $\&$ ltype $=$ pin $\& \mathrm{r}-$ type $=b \&$ pin $=\& r s e=0 \&$ maptype $=0$.

Energy Information Administration (EIA), 2018f, Count of electric power industry power plants, by sector, by predominant energy sources within plant: U.S. Energy Information Administration, Office of Coal, Nuclear, Electric and Alternative Fuels, U.S. Department of Energy, accessed Feb. 25, 2019, at URL https://www.eia.gov/electricity/annual/html/ epa_04_01.html. 
Energy Information Administration (EIA), 2018g, USA coal production, consumption, export and import: U.S. Energy Information Administration, Office of Coal, Nuclear, Electric and Alternative Fuels, U.S. Department of Energy, accessed Feb. 1, 2019, at URL https://www.eia.gov/energyexplained/index.php?page $=$ coal_imports.

Energy Information Administration (EIA), 2018h, Indiana State Profile and Energy Estimates. U.S. Energy Information Administration, Office of Coal, Nuclear, Electric and Alternative Fuels: U.S. Department of Energy, accessed Feb. 5, 2019, at URL https://www.eia.gov/state/analysis. php?sid=IN.

Energy Information Administration (EIA), 2018i, U.S. maps: U.S. Energy Information Administration, Office of Coal, Nuclear, Electric and Alternative Fuels, U.S. Department of Energy, accessed May 7, 2019, at URL https://www.eia.gov/ maps/layer_info-m.php.

Energy Information Administration (EIA), 2018j, U.S. electricity generation by energy source: U.S. Energy Information Administration, Office of Coal, Nuclear, Electric and Alternative Fuels, U.S. Department of Energy, accessed Feb. 5, 2019, at URL https://www.eia.gov/tools/faqs/faq. $\mathrm{php}$ ? id $=427 \& \mathrm{t}=3$.

Euracoal, 2012, Coal producing countries in Europe: European Association for Coal and Lignite, accessed Jan. 15, 2019, at URL https:/euracoal.eu/info/euracoal-eu-statistics/.

Federal Reserve Board of St. Louis, 2019, Total employment in coal mining: Federal Reserve Board of St. Louis website, accessed Feb. 1, 2019, at URL https://fred.stlouisfed.org/ series/CEU1021210001\#0.

French, E., and Hanes, R. C., 2006. Hopis-countries and cultures: World Culture Encyclopedia, accessed Jan. 5, 2019, at URL https://www.everyculture.com/multi/Ha-La/Hopis.html.

Indiana Bureau of Mines, 1973-1997, Indiana coal production, accessed Feb. 5, 2019, at URL https://www.in.gov/dol/ mines.htm.

Indiana Coal Council, 2018, Indiana coal production: Indiana Coal Council website, accessed Feb. 15, 2019, at URL http:// www.indianacoal.com/indiana-coal-production.html.

Jaireth, S., and Huleatt, M., 2012, Australian coal resources [1:10,000,000 scale map]: Canberra, Australia, Geoscience Australia, accessed Jan. 6, 2019, at URL https://d28rz98at9flks.cloudfront.net/74097/74097.pdf.

Karlsen, A. W., Schultz, A. C., Warwick, P. D., Podwysocki, M., and Lovern, V. S., 2001, Coal geology, land use, and human health in the People's Republic of China: U.S. Geological Survey Open-File Report 2001-318, accessed December 12, 2019, at URL http://pubs.er.usgs.gov/publication/ofr01318.

Kentucky Geological Survey, 2014, Coal production database: Kentucky Geological Survey website, accessed Feb. 15, 2019, at URL https://kgs.uky.edu/kgsweb/DataSearching/ Coal/Production/prodsearch.asp.

Kentucky Office of Energy Policy, 2018, Kentucky quarterly coal report-July to September 2018: Kentucky Office of Energy Policy, accessed February 1, 2019, at URL https://eec. ky.gov/Energy/News-Publications/Quarterly\%20Coal\%20 Reports/2018-Q3.pdf.
Mastalerz, M., Drobniak, A., Rupp, J., and Shaffer, N., 2009, Characterization of Indiana's coal resource-availibility of the reserves, physical and chemical properties of the coal, and present and future uses: Indiana Geological Survey Special Report 66.

Merrill, M. D., and Tewalt, S. J., 2008, GIS representation of coal-bearing areas in Africa: U.S. Geological Survey OpenFile Report 2008-1258, accessed December 13, 2019, at URL http://pubs.usgs.gov/of/2008/1258/.

Tewalt, S. J., Kinney, S. A., and Merrill, M. D., 2008, GIS representation of coal-bearing areas in North, Central, and South America. U.S. Geological Survey Open-File Report 20081257, accessed December 12, 2019, at URL http://pubs.usgs. gov/of/2008/1257.

Trippi, M. H., and Tewalt, S. J., 2011, Geographic information system (GIS) representation of coal-bearing areas in India and Bangladesh: U.S. Geological Survey Open-File Report 2011-1296, 27 p., accessed Dec. 12, 2019, at URL http:// pubs.usgs.gov/of/2011/1296.

U.S. Bureau of Mines, 2018, Indiana coal production: National Archives website, accessed Dec. 12, 2018, at URL https:// www.archives.gov/research/guide-fed-records/groups/070. html.

U.S. Department of Labor, 2017, Mine Safety and Health Administration's number of coal and non-fuel minerals operations in the U.S. 1979-2016: National Mining Association website, accessed Feb. 1, 2019, at URL https://nma.org/ wp-content/uploads/2017/01/msha_number_operations_ by_sector_2016.pdf. 